\title{
Tropical Cyclones in the North Atlantic Basin and Yucatan Peninsula, Mexico: Identification of Extreme Events
}

\author{
Gabriel Sánchez-Rivera ${ }^{1,5^{*}}$, Oscar Frausto-Martínez ${ }^{1,5}$, Leticia Gómez-Mendoza ${ }^{2,5}$, Ángel Refugio Terán-Cuevas ${ }^{3}$, \\ Julio Cesar Morales Hernández ${ }^{4,5}$
}

\begin{abstract}
${ }^{1}$ Laboratorio de Observación e Investigación Espacial, Universidad de Quintana Roo; Avenida Andrés Quintana Roo, S/N, Frente a colonia San Gervasio, Cozumel 77600, Quintana Roo, Mexico

${ }^{2}$ Colegio de Geografía, Facultad de Filosofía y Letras, Universidad Nacional Autónoma de México, Ciudad Universitaria, Coyoacán 04510, Ciudad de Mexico, Mexico

${ }^{3}$ Centro Interdisciplinario de Investigaciones y Estudios sobre Medio Ambiente y Desarrollo, Instituto Politécnico Nacional (CIIEMAD-IPN), Departamento de Territorio y Ambiente, 30 de Junio de 1520 s/n, La Laguna Ticomán, Gustavo A. Madero, 07340, Ciudad de México, Mexico

${ }^{4}$ Centro de Estudios Meteorológicos de la Costa, Departamento de Ciencias Exactas, Centro Universitario de la Costa, Universidad de Guadalajara, Av. Juárez No. 976, Colonia Centro, Guadalajara 44100, Jalisco, Mexico

${ }^{5}$ Red de Desastres Asociados a Fenómenos Hidrometeorológicos y Climáticos (REDESClim), CONACYT, Av. Insurgentes Sur 1582, Col. Crédito Constructor, Alcaldía Benito Juárez, Ciudad de México 03940, México
\end{abstract}

Corresponding Author Email: grivera@uqroo.edu.mx

https://doi.org/10.18280/ijdne.160204

Received: 19 October 2020

Accepted: 22 March 2021

\section{Keywords:}

extreme events, hurricanes, percentiles, North Atlantic, Yucatan Peninsula

\begin{abstract}
Tropical cyclones impact continental and island lands annually, so attention to the adverse effects of associated winds and rains is focused on damage to human settlements, growing areas, infrastructure, loss of human life, and ecosystems. Defining the concept of extreme events is complex since it depends on the focus with which it is approached. The study aimed to provide a long-term and large-scale Serie (168 years) concerning cyclonic activity and characterization of extreme cyclones in the North Atlantic Basin, considering as a reference the World Meteorological definition Organization. The trend of extreme events in the 1851-2019 period was calculated from the records of the International Best Track Archive for Climate Stewardship and the statistical method "Exceeding a relative threshold," from the variables: "maximum speed of sustained winds" and "minimum atmospheric pressure." The thresholds considered were a) 10 and 90; b) 1 and 99; and c) extraordinary maximum threshold of 0.1 and 99.9 (percentiles). The cyclone trajectories were classified based on a) did not landfall; b) They impacted continental and insular lands; c) They impacted Mexico; and d) They impacted the Yucatan Peninsula. The results showed that of the total of 2,220 events registered, 59\% $(n=1,302)$ touched land. Considering the laxest thresholds (10 and 90 percentiles), the number of extreme events identified for the North Atlantic was $5.95 \%(n=132)$, while for the Yucatan Peninsula, it was $0.72 \%(n=16)$. The findings do not show a significant trend of increasing cyclone numbers. As for intensity (magnitude), a slight increase in hurricanes in categories H4 and H5 on the Saffir-Simpson scale has been observed in the last two decades.
\end{abstract}

\section{INTRODUCTION}

Tropical cyclones (TCs) impact continental and island lands annually, the National Hurricane Center (NHC) defines them as: "a closed atmospheric circulation that rotates counterclockwise in the northern hemisphere and clockwise in the southern hemisphere" [1], represented by an organized system of clouds and electrical storms originating in tropical or subtropical waters with a closed low-level circulation [2], which can be characterized on the measurement and estimation of their physical and temporal properties, such as intensity (magnitude), measured as a function of the maximum speed of sustained winds (Max. Win.) and minimum atmospheric pressure (Min. Pres.), trajectory (location), precipitation, duration, travel speed, among others [3]. The measurement of the intensity and destruction capacity of tropical cyclones is estimated based on a scale developed by the wind engineer Herb Saffir and the meteorologist Bob Simpson, which is called the "Saffir-Simpson scale (SS)" [4].

To compensate for the catastrophic perception of the effect of cyclones, Vink and Ahsan [5] carried out a study where they identified through the literature records those benefits that these events provide; their results reported the finding of 14 types of direct benefits and two indirect, classified based on the categories of provisioning, regulation, support, and cultural aspects, proposed for ecosystem services of the United Nations Environment Program (UNEP) [6].

According to Appendini et al. [7], TCs are events that can cause the economy, the population's physical integrity, and severe environmental damages. The effects of climate change will be reflected in the increase in the number and intensity of such events, which increase exposure to higher intensity winds 
and rainfall will have repercussions on the vulnerability of social and environmental systems [8].

The design and implementation of mitigation and adaptation measures require identifying and characterizing changes in extreme events' dynamics.

The main objectives of this study were to provide a longterm scenario of cyclonic activity in the North Atlantic Basin (NAB) and the characterization of extreme cyclones, according to the World Meteorological Organization (WMO) [9], who states that the events considered "rare" are those that exceed the 90th and 95th percentiles. In contrast, those considered "very rare" would exceed the rank of 99 or higher. Therefore, an added reference criterion (extreme threshold) of the order of 0.1 and 99.9 percentiles were included; with this, we sought to identify events that can be considered "extraordinarily rare."

To answer the questions and objectives raised, we used the records of cyclones that occurred in the last 168 years from the database of the International Best Track Archive for Climate Stewardship (IBTrACS) [10], considering the "maximum speed sustained winds" and "minimum atmospheric pressure." The description of the information's characteristics and the source data's uncertainty degrees are addressed in the "data" section.

In the characterization of extreme events, the statistical model "exceeding a relative threshold" was applied, taking as reference three sets of thresholds based on the percentiles proposed by the Intergovernmental Panel on Climate Change (IPCC) $[11,12]$ and Camuffo, della Valle, \& Becherini [13].

Results are presented from general to particular cases, beginning with the events' characterization at the NAB scale and ending with identifying the extreme events that have impacted the Yucatan Peninsula (YP). For this, four phases were defined and executed, described in the "methods" section.

The study allowed us to identify the trend of the formation (quantity) and intensity (magnitude) of the tropical cyclones in the extreme category, 260 for the NAB, of which 30 crossed the YP. The identification of four hurricanes characterized as "extremely rare" stands out, of which Gilbert (1988) and Wilma (2005) landfall the YP.

The research will allow having a frame of reference regarding the classification of tropical cyclones extreme events under the definition proposed by the WMO, which will serve as a reference to correlate the effects caused by TCs based on the probability of the increase in the according to the $\mathrm{CC}$ scenarios.

\section{BACKGROUND}

The characterization of extreme events involves a conceptualization problem; Stephenson [14] mentions that there is no consensus as to what is meant by "extreme," so the lack of a single definition has given rise to various statements, which depend on the context and the attributes considered, such as frequency, intensity, duration, spatial scale, effects on environmental components and human infrastructure, among others. Also, the words "severe," "rare," "high impact," and "extreme" are often used interchangeably and synonymously, making it even more confusing and complicated to reach an agreement to define what is an "extreme event." The author proposes a classification that allows ranking extreme meteorological and climatic phenomena, differentiating and integrating the "rare," "severe," "extreme" and "high-impact" concepts, where cyclones being in the extreme category, those whose occurrence is "rare," with "severe" and "acute" effects, where "rare" is defined as that event with a low probability of happening.

In the scientific literature consulted, no single method was found to characterize extreme events; on the contrary, definitions such as those proposed from meteorology and climatology vs. ecological and social approaches tend to be opposite. In the first case, the WMO [7] proposes as a general principle that the definition of extreme events must consider the physical and spatio-temporal characteristics of the phenomenon studied (the threat or danger), independent of the impact that could cause, while in the second case states that they must be defined upon the impact and the effects caused (vulnerability) on the natural and social environment [13-16].

Due to the complexity in defining extreme events, the WMO [17] presented a compilation of the findings in the scientific literature on the perspectives used for its characterization, distinguishing eight classes: a) basic descriptive variables; b) derived variables; c) threshold categorization; d) human perspective of extremes; e) hydrological/agriculture; f) derived indices; g) basic hydrological/climatological indices, and h) expert interpretation/classification of drought. The " $h "$ type category, in turn, is divided into three subcategories: 1) extremes of atmospheric weather and climate variables, 2) large-scale phenomena accounting for extremes, and 3) collateral effects of extremes on the physical environment. The most widely used classifications in the climate science field are single, variable, and compound (multivariable) ends.

The definition of the IPCC $[11,12]$ falls within class "h," category "1", which defines them as those that present values of a climatic or weather variable above or below a relative threshold value to the upper or lower extremes of the range of observed values of the considered variable, being in the 10th or 90 th percentile of the probability density function. Camuffo et al. [13] point out that the percentiles should be on the order of 1 and 99, given that the proposed by the IPCC is unrealistic.

Stephenson [16] and Camuffo et al. [13] identified among the main statistical models to characterize extreme climatic events the following: a) Peak over a threshold [11]; b) Extreme value theory $[18,19]$; c) Exceeding a relative threshold [12]; d) exceeds a threshold and a return period [17]; and e) Effectiveness: events that trigger a disaster or emergency [12] or capable of causing injury and loss of life, etc. [17].

Statistically, the occurrence of extreme events is rare in terms of frequency, magnitude, or duration in a particular ecosystem, so recognizing them will be a function of the length and quality of the observation records and cannot be described from a single quantity, so it is advisable to include variables that allow identifying the effects and damages caused by phenomena that landfall $[13,14]$.

The characterization of hurricanes as extreme events is of interest when considering the climate change scenarios, which foresee an increase in their quantity and intensity [20]; an increase that will not occur suddenly but gradually, so that the detection of changes will be possible through the analysis of long time series.

From another perspective, several authors have sought to identify patterns that allow understanding and comprehend the dynamics related to the occurrence of tropical cyclones through the correlation of various variables such as ocean surface temperature, sunspot activity, Southern Oscillation (ENSO), and the multidecadal oscillation of the Atlantic 
Ocean (AMO). Examples are the works published by Holland \& Bruyère [21]; Doval \& Rodríguez [22]; Vecchi \& Knutson [23] and Klotzbach [24].

In Mexico's case, numerous studies have addressed the analysis of cyclones in the YP, among which those of PalacioAponte [25] and Ihl \& Frausto [26] stand out. They estimate the areas of greatest danger and probability of impact, highlighting the north and northeast coastal areas of the Peninsula as "extreme danger" areas, followed by the south of Quintana Roo. Furthermore, others like Frausto et al. [27] based on the design and implementation of indicators to monitor and control the resilience capacities of areas susceptible to cyclones' impact.

However, those studies do not address the concept of extreme events considering the definitions of the WMO and the IPCC. The same situation occurs with the National Oceanic and Atmospheric Administration (NOAA), IBTrACS, and the National Water Commission (CONAGUA, due to its Spanish acronym) databases, which get limited to presenting information about socio-economic impacts and loss of human life according to the SS Scale.

Given the above, the following questions were asked: a) has there been an increase in the number and intensity of cyclones formed in the North Atlantic Basin between the 1851-2019 period? b) which cyclones formed in the North Atlantic Basin does it meet the definitions of extreme events proposed by the
WMO and the IPCC? and c) which cyclones categorized as extreme has landfall the Yucatan Peninsula?

\section{MATERIALS AND METHODS}

\subsection{Study area}

The study area corresponds to the North Atlantic Basin. It includes the regions of Canada and the USA's eastern coasts to the northwest and the sub-basins of the Gulf of Mexico and the Caribbean Sea to the east and southeast (Figure 1). According to data from the Flanders Marine Institute [28], the basin covers an approximate surface of 59.5 million $\mathrm{km} 2$, where 3 million correspond to the Caribbean Sea and 1.9 to the Gulf of Mexico. Along its perimeter, many countries and coastal populations are susceptible to suffering the direct impacts of cyclones in the extreme category. The Caribbean Sea region alone includes 28 islands recognized as countries, with a population of the order of 43 million inhabitants estimated by 2020 [29].

The results presented by Knapp et al. [31] place the North Atlantic Basin in third place in terms of the number of cyclones reported between the years 1940 and 2010, occupying first and second place the Western and Eastern Pacific Basins, respectively.

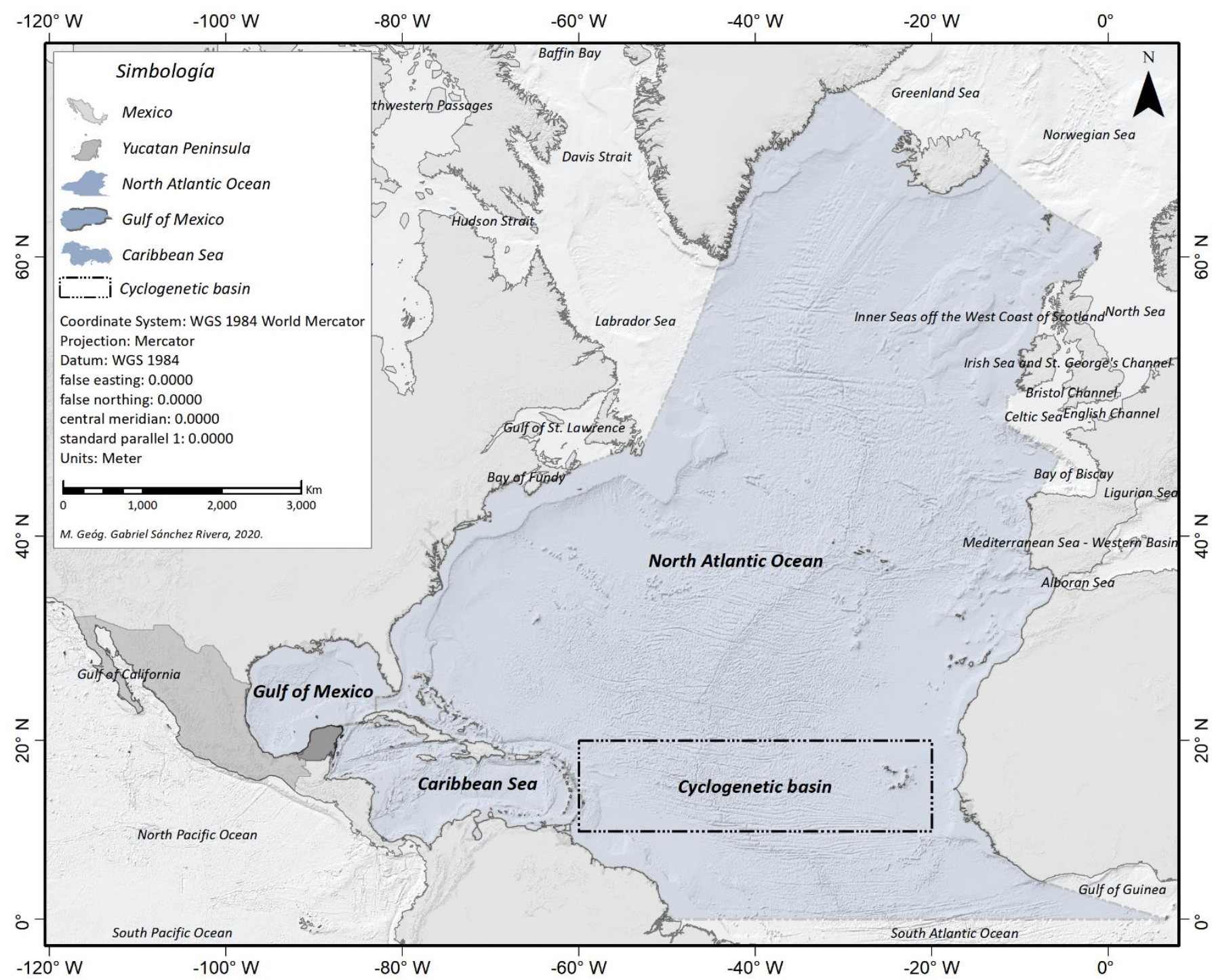

Figure 1. North Atlantic Basin. Source: elaborated with data from Amante \& Eakins [30], Flanders Marine Institute [28] 
The main development zone for cyclonic events is located between the coordinates: $10^{\circ} \mathrm{N}-20^{\circ} \mathrm{N}$ and $20^{\circ} \mathrm{W}-60^{\circ} \mathrm{W}$, between Cape Verde's islands and the Caribbean's Lesser Antilles [32].

\subsection{Data}

Information on the physical characteristics and trajectory of tropical cyclones in the NAB was obtained from the IBTrACS [10] repertoire; best track data are free to access, updated daily in a time interval of 3-hour and contain provisional tracks of recent storms; the data is available in 3 formats (netCDF, CSV, shapefiles). We use the release "v04r00" on 09-09-2019. The files are presented in alphanumeric and vector format, which contains 119,626 individual records that make up 2,220 meteors reported between June 23, 1851, and September 05, 2019.

The data results from the post-cyclone season analysis when all the information available for each event is processed. So, the historical record is not homogeneous in its construction [33]; additionally, the origin of the records from various historical sources made from different techniques and ranges of precision present different spatial-temporal variations of origin depending on the agencies and sources consulted [31].

In the case of wind speed, the degree of uncertainty measured in knots decreases temporarily, reaching the following maximum levels: years before 1965 of $\pm 30,1965$ 1978 of $\pm 20 ; 1978-1984$ of $\pm 15 ; 1984-2000$ of \pm 10 ; and from 2000 to date, it drops to \pm 7 knots. The atmospheric pressure oscillates in the order of $1 \mathrm{mb}$, and the position is reported at a resolution of approximately $0.1^{\circ}$, which results in an uncertainty of approximately $\pm 10 \mathrm{~km} \mathrm{[3].}$

Regarding atmospheric pressure, the primary source of records begins from the end of the Second World War with manned aircraft equipped with sensors for their measurement and later with the incorporation of satellites in the 1960s. Therefore, the absence of data for more than $50 \%$ of the NAB's cyclones stands out. Additionally, spatial variations can also occur because of the intensity of cyclonic phenomena [34].

To identify the cyclones that made landfall, we used the global vector files of the coasts of the: "A Global Selfconsistent, Hierarchical, High-resolution Geography Database" [35, 36] and the polygons that delimit the NAB and the sub-basins of the Gulf of Mexico and the Caribbean Sea of the Flanders Marine Institute [28].

\subsection{Methods}

The processes to reach the aims of the study were grouped into four phases (Figure 2):

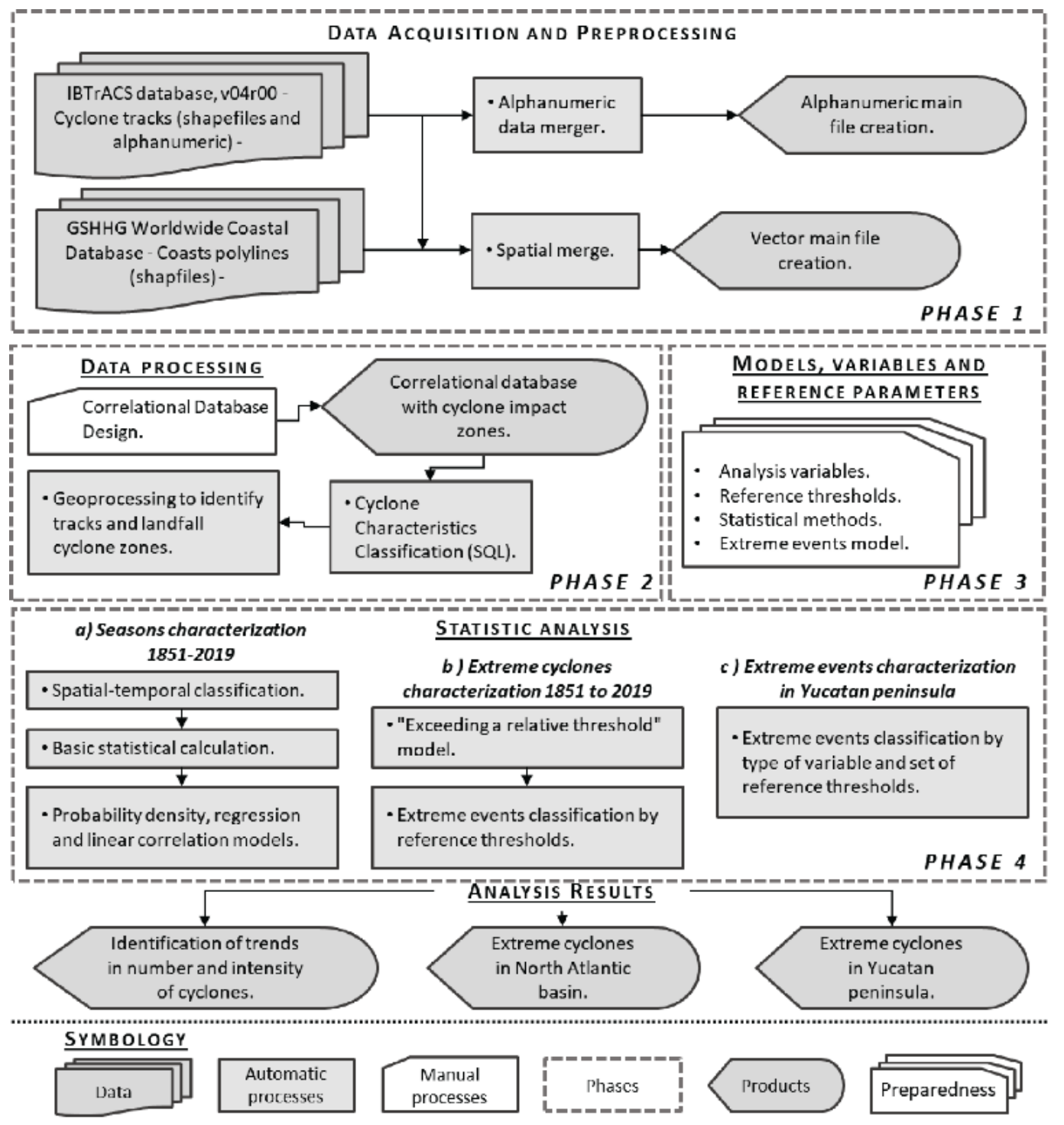

Figure 2. Methodological diagram 
Phase 1: Data acquisition and pre-processing. The vector layers were re-projected to UTM-GCS_WGS_1984, the units of the alphanumeric files were converted to the decimal metric system. Subsequently, two base files were created: the trajectory vector layer and alphanumeric database with each cyclone's records.

Given that the precision of the information is a function of each cyclone's particular characteristics and that it is not reported individually, for the analysis of the distribution and trend of cyclonic events, the data reported by the IBTrACS were considered as average values and preadjusted from the origin. Nevertheless, during the analysis of results, uncertainty was always considered, particularly for those events before the '80s of the 20th century.

Phase 2: Data processing. A correlation database was designed in the MS-Access program, and various queries were generated through the SQL language to classify and analyze meteors, such as the number of events per year, per month, per category, among others. The impact zones were identified by geoprocessing the vector layers in the ArcGis 10.3 program, classifying them into four classes: a) they did not landfall; b) impacted continental and insular lands; c) impacted Mexican lands, and d) impacted the Yucatan Peninsula. The results were integrated into the database to generate queries by type of impact zone.

Phase 3: Models' choice, variables, and reference parameters. To identify the trend patterns of the analyzed events were applied, statistical models of change rates, linear regression (least squares), and calculation of Pearson and Spearman's linear correlation coefficients. In the characterization of extreme cyclonic activity, the models "probability density function" and "Exceeding a relative threshold" was selected, considering the variables "wind speed" and "atmospheric pressure," which were analyzed taking the percentiles as reference parameters 10-90; 1-99 and 0.1-99.9.

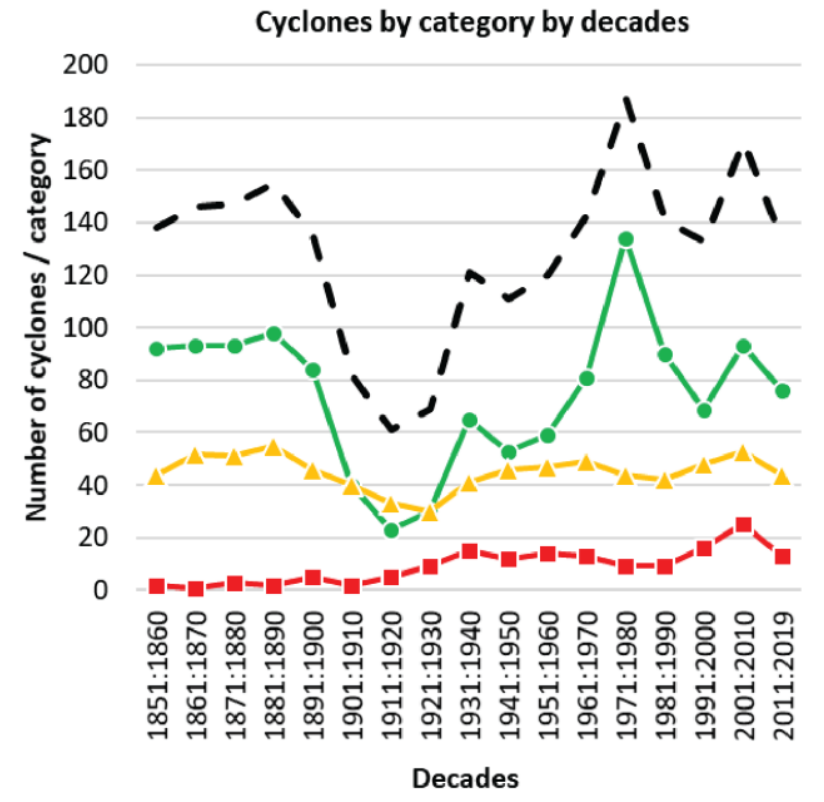

Phase 4: Statistical analysis. a) identifying trends of change in cyclones' number and intensity through queries in the correlated database for spatio-temporal classification, by decades, categories (intensity), and impact zones. The data was exported to the MiniTab 17 statistical program to calculate the basic descriptive statistics by analysis variable, the probability density function, the rates of change based on the trend line equation, and the regression and linear correlation models, which that allowed estimating the annual distribution of the number of cyclones vs. intensity and speed of the wind vs. atmospheric pressure; b) identification and characterization of extreme hurricanes from the "Exceeding a relative threshold" model at two levels: i) independent variables (wind speed and atmospheric pressure), and ii) compound variables (wind speed vs. atmospheric pressure), contrasting the sets of "reference thresholds" vs. "analysis variables"; and c) queries in the correlated database to identify extreme hurricanes over YP.

The study presents the results as follows: a) characterization of cyclonic phenomena at the NAB level by impact zones; b) characterization of extreme cyclones based on the selected analysis criteria and variables; and c) extreme hurricanes on the YP.

\section{RESULTS}

\subsection{Characterization of the seasons 1851 to 2019}

4.1.1 Analysis of trends in the number and intensity of tropical cyclones

IBTrACS records report a total of 2,220 storms for NAB, of which 2,193 (99\%) reached the SS scale. To identify trends in cyclones' number and intensity, they were grouped into three categories: i) depressions and tropical storms; ii) hurricanes $\mathrm{H} 1$ to H3; and iii) hurricanes H4 and H5 (Figure 3).

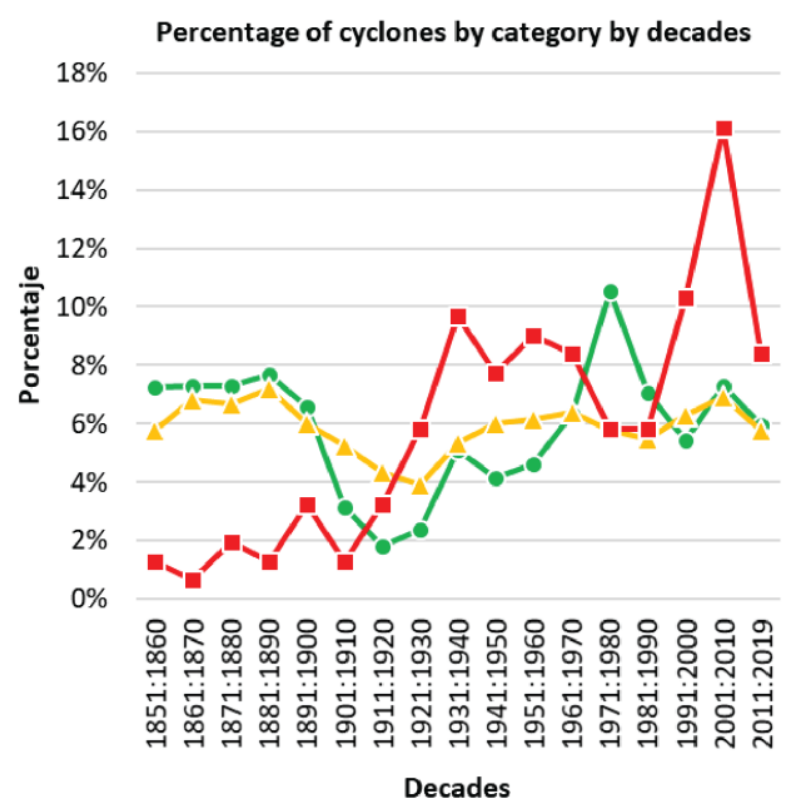

Symbology: $\quad-\bullet-T D+T S$

$-\mathrm{H} 1+\mathrm{H} 2+\mathrm{H} 3-\mathrm{H}-\mathrm{H} 4+\mathrm{H} 5-$ Total cyclones

Figure 3. Cyclone intensity grouped by categories according to the SS scale for decades between 1851-2019

where: a) green line represents the sum of the cyclones that do not reach the hurricane category; yellow line sum of hurricanes categories 1,2, and 3; red line sum of hurricanes categories 4 and 5; and dotted black line, total cyclones. b) equivalent to -a) - but standing for the percentage concerning the cyclone's total per decade. Where: TD = Tropical Depression; TS = Tropical Storm; and H = Hurricane categories 1 to 5. Source: Adapted from Webster [37], updated with data from IBTrACS [10] 


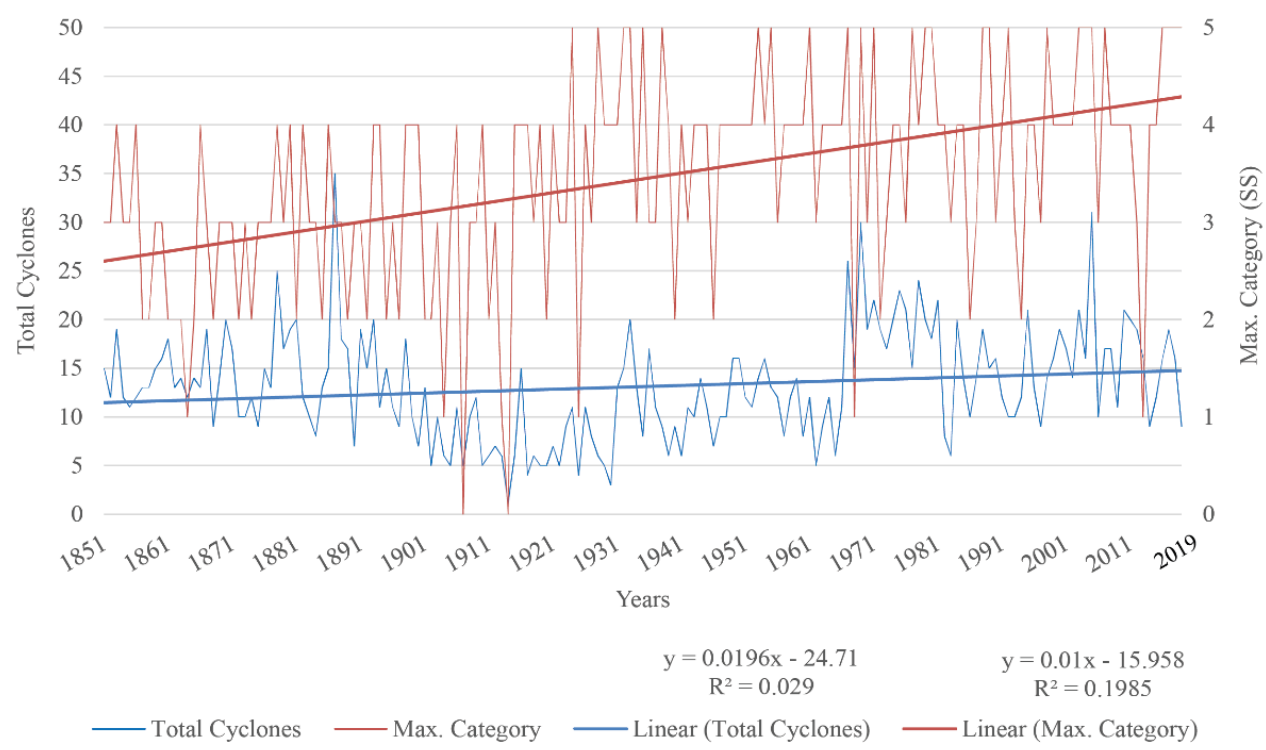

(a)

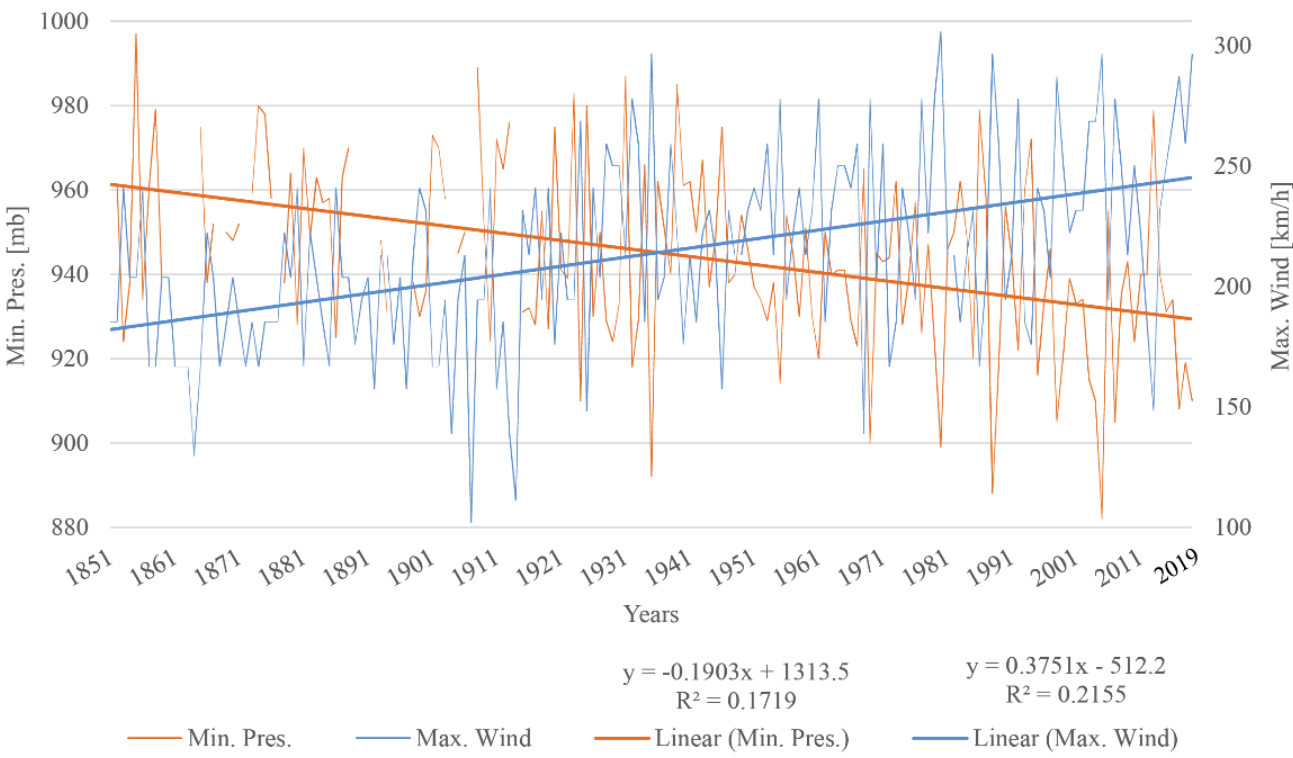

(b)

Figure 4. Annual distribution and linear trend analysis in the North Atlantic: a) total (number) and SS category (intensity) of cyclones; b) minimum atmospheric pressure and maximum speed of sustained winds

where: Spearman's rho linear correlation coefficient has a value of $\mathrm{R}^{2}=-0.95$, which corroborates the proportional inverse relationship between both variables

Figure 3 a shows the sum of meteors by category per decade, where the '20s of the 20th century stand out with the lowest number (61 cyclones) and the first in which a category H5 cyclone is recorded, in addition to being the only one with more hurricanes $\mathrm{H} 1$ to $\mathrm{H} 3$ recorded than depressions and tropical storms, a fact that may be due to the loss of records at sea during and after World War I [38]. In contrast, the 1970s reported the most with 200 cyclones.

The percentages to identify the behavior of the intensity of cyclones were calculated by groups of categories concerning the total by decade; in Figure 3b, it can be seen that between 1930 and 1970, there was a rebound of hurricanes H4 and H5, but it is in the past three decades when there is the most significant tendency to increase in proportion to the total number of meteors formed per decade. 2005 was characterized by presenting the most considerable amount with four hurricanes in H5 category (Emily, Katrina, Rita, and Wilma), and maintaining itself as the year with the most intense cyclonic formation recorded in the history of the North
Atlantic, represented by Hurricane Wilma.

The calculation of the trend line for the variables number of cyclones and category reveals that the values given their variability do not present a significant adjustment, returning $\mathrm{R}^{2}$ values of the order of 0.029 and 0.199 , respectively (Figure 4a). The rates of change based on the trend lines' equations show in the number of cyclones an increase of less than $2 \%$ and the intensity (SS category) of only $1 \%$.

Considering that the Saffir-Simpson scale represents ranges and not absolute speeds, to identify the behavior of cyclone intensity, the linear trend of the variables "atmospheric pressure" and "wind speed" was calculated, obtaining values of $\mathrm{R}^{2}$ of the order of 0.17 and 0.2 , respectively, indicating a low adjustment with the trend line (Figure 4b). Calculating the change rates based on the trend line equation showed an average decrease of $-19 \%$ for atmospheric pressure and an increase of close to $38 \%$ for wind speed.

Linear regression showed an inversely proportional significant relationship with an $\mathrm{R}^{2}$ value of 89.5 , consistent 
with the results of the calculation of Pearson and Spearman rho linear correlation coefficients (values of -0.95 ); which corroborates that at lower pressure, higher wind intensity, a behavior known and widely described in the meteorological literature [39-42].
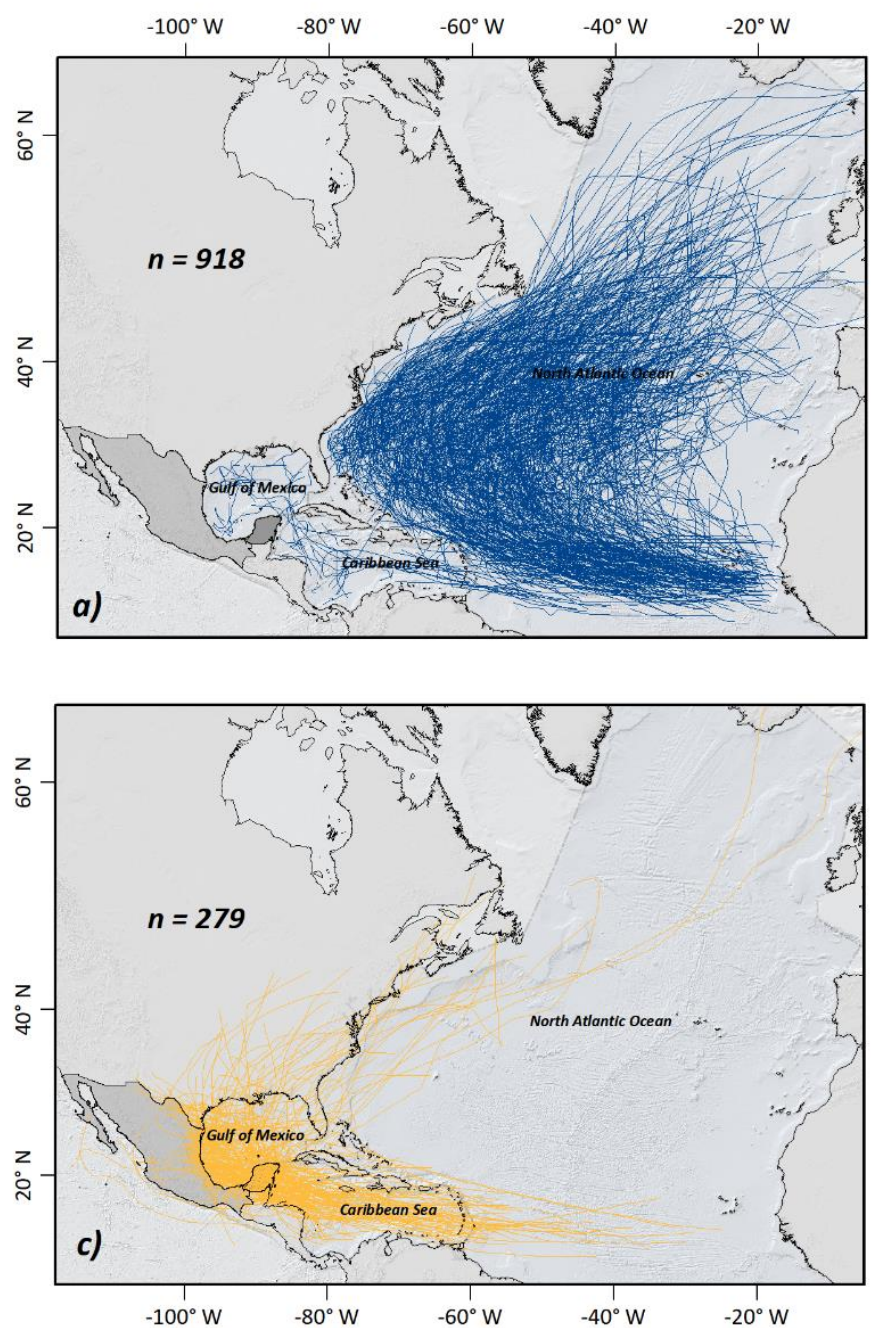

Symbology b) Continental and insular landfall d) Yucatan peninsula landfall

4.1.2 Spatial distribution of tropical cyclones

Of the registered tropical systems, 59\% touched continental or insular lands; of this, $21 \%$ impacted Mexico, and 13\% the Yucatan Peninsula; the spatial distribution is presented in Figure 5.
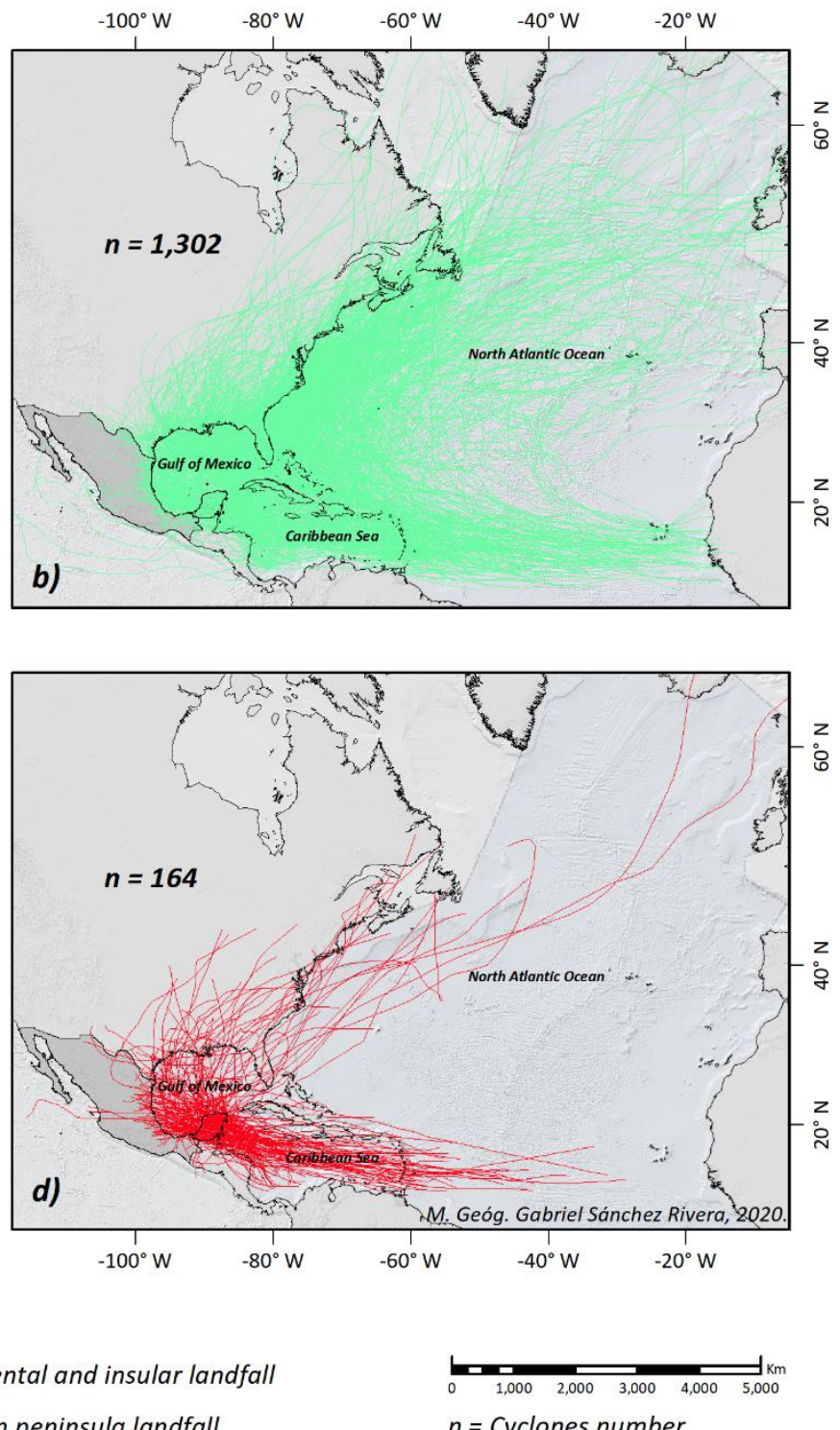
$n=$ Cyclones number

c) Mexico landfall

Figure 5. Tropical cyclones track classified by impact zone. a) Did not landfall; b) Continental and insular landfall; c) Mexico landfall; and d) Yucatan Peninsula landfall

where: Continental and insular landfall include Mexico, and Mexico landfall includes the Yucatan Peninsula

\subsection{Characterization of tropical cyclones as extreme events in the period 1851 to 2019}

Wind speed data are available for $84 \%$ of cases and atmospheric pressure around 50\% (Table 1). Regarding extreme values, the maximum reported wind speed is 305 $\mathrm{km} / \mathrm{h}$ for hurricane Allen (1980, H5)), and the minimum pressure is $882 \mathrm{mb}$ for hurricane Wilma $(2005, \mathrm{H} 5)$.

\subsubsection{Characterization of extreme cyclones}

To identify the values that exceeded the selected relative thresholds, we applied the "Exceeding a relative threshold" model for each of the reference variables independently. The box diagrams (Figure 6) show that of the total, five cyclones reported values higher than $296 \mathrm{~km} / \mathrm{h}$ and ten underneath than $908 \mathrm{mb}$, being considered as outliers given that they exceed the respective interquartile range by more than 1.5 times.

The values that exceed the established thresholds and are considered "rare" were obtained using the probability density function. Figure 7 shows the ranges for maximum winds and minimum pressure for each set of thresholds (percentiles) selected.

The number of extreme events to each variable analyzed independently and based on the thresholds proposed by the IPCC $[11,12]$ is $257(11.58 \%)$ for wind speed and $132(5.95 \%)$ for atmospheric pressure. The total extreme hurricanes identified for each of the three selected thresholds by their trajectories are shown in Figures 8 and 9. 
Table 1. Basic descriptive statistics for each variable where: $\mathrm{N}=$ records with data and $\mathrm{N} *=$ records without data

\begin{tabular}{ccccccc}
\hline Variable & N & N* & Percent & Mean & StDev & Min. \\
\hline Max Wind $[\mathbf{k m} / \mathbf{h}]$ & $1,859.00$ & 361.00 & 83.74 & 125.96 & 54.32 & 46.30 \\
\hline Min Pres $[\mathbf{m b}]$ & $1,090.00$ & $1,130.00$ & 49.10 & 978.51 & 24.46 & 882.00 \\
\hline Variable & Max. & $\mathbf{Q 1}$ & $\mathbf{Q 3}$ & Mode & Skewness & Kurtosis \\
\hline Max Wind $[\mathbf{k m} / \mathbf{h}]$ & 305.58 & 83.34 & 166.68 & 92.60 & 0.61 & -0.20 \\
\hline Min Pres $[\mathbf{m b}]$ & $1,016.00$ & 963.00 & 999.00 & $1,000.00$ & -0.91 & 0.27 \\
\hline
\end{tabular}
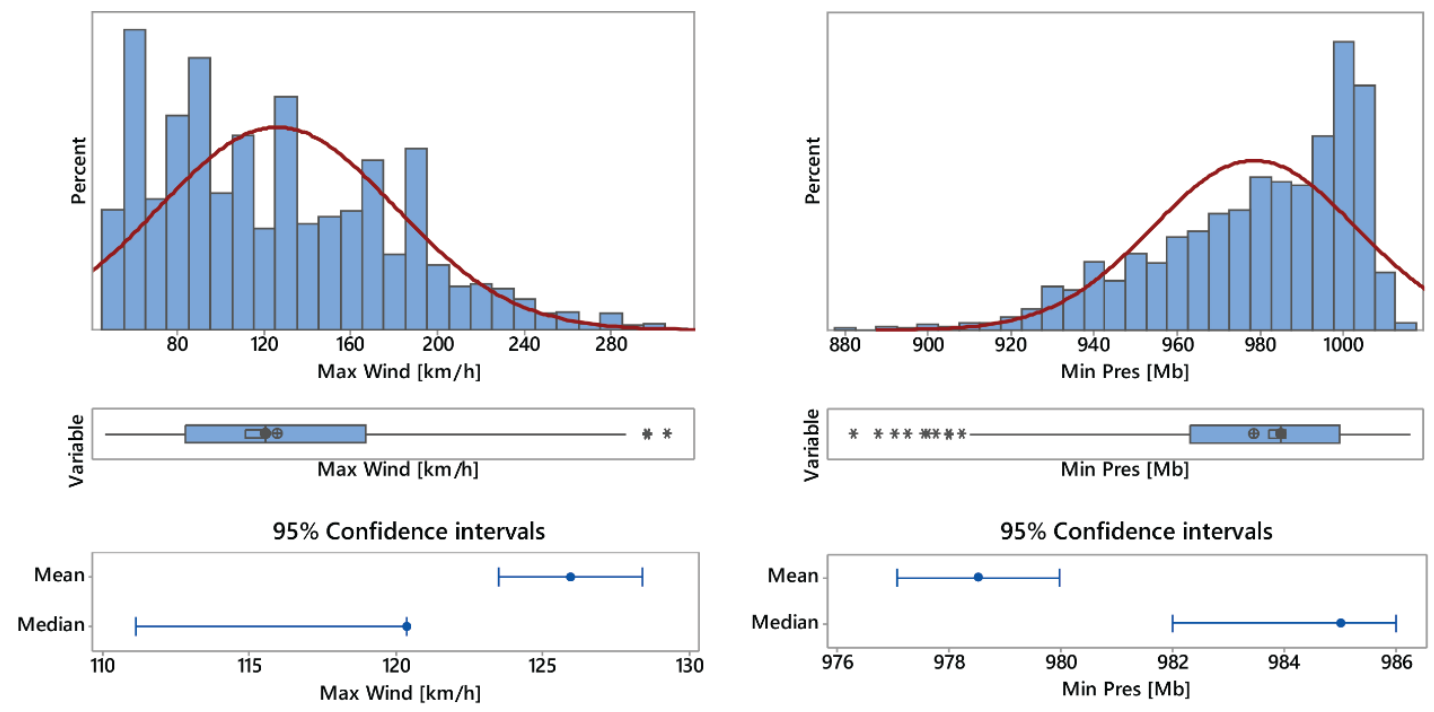

Individual standard deviations were used to calculate the intervals.

Figure 6. Statistical summary (histogram and box plot): a) Maximum speed of sustained winds [km/h]; b) Minimum atmospheric pressure $[\mathrm{mb}]$
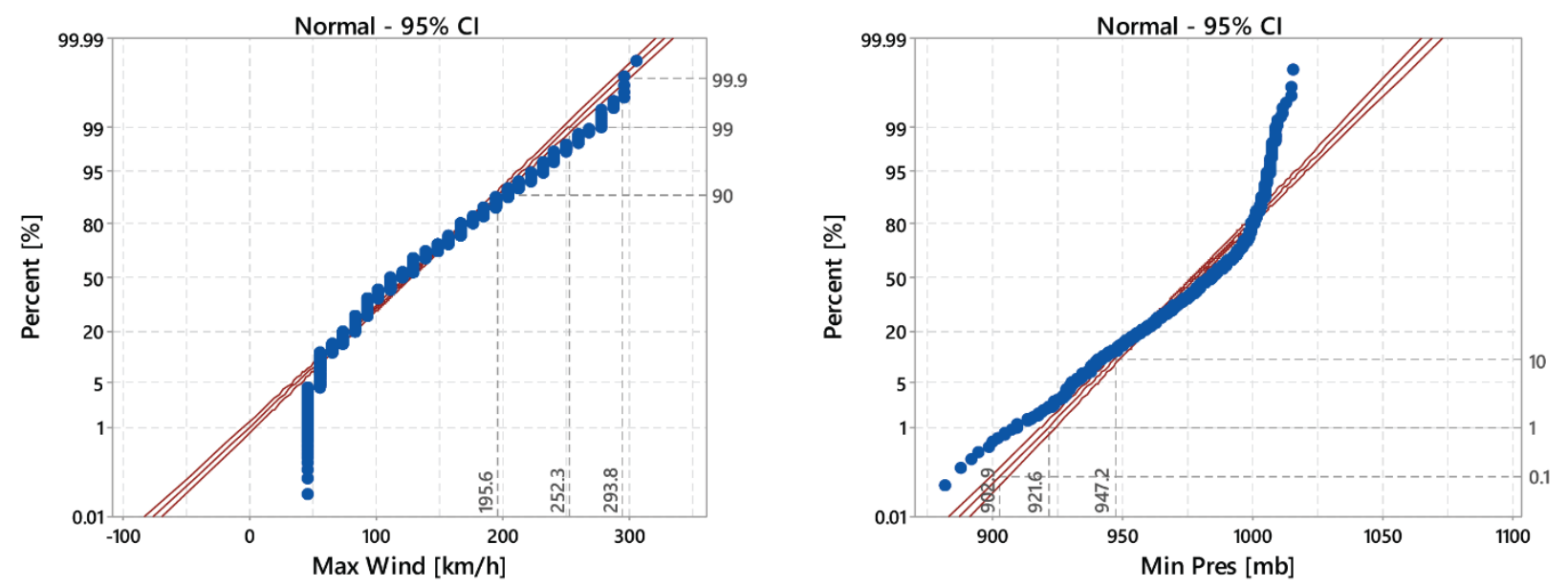

Figure 7. Probability function: a) maximum speed of sustained winds $[\mathrm{km} / \mathrm{h}]$; b) minimum atmospheric pressure [mb]

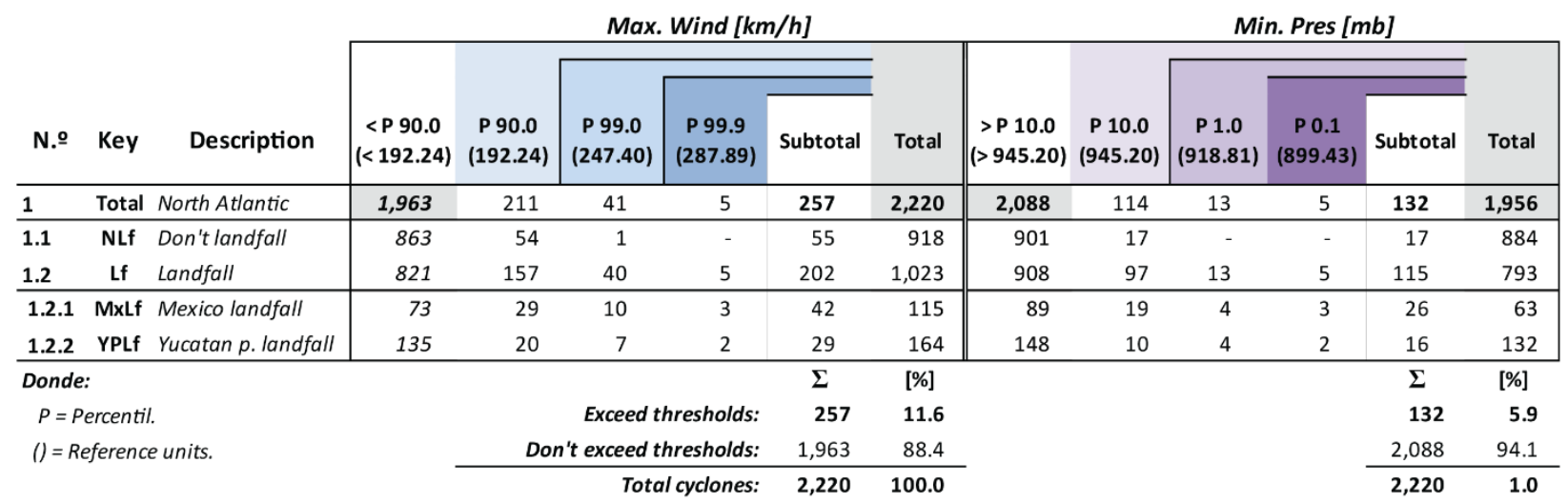

Figure 8. Extreme cyclones in the North Atlantic Basin by thresholds by analysis variable 

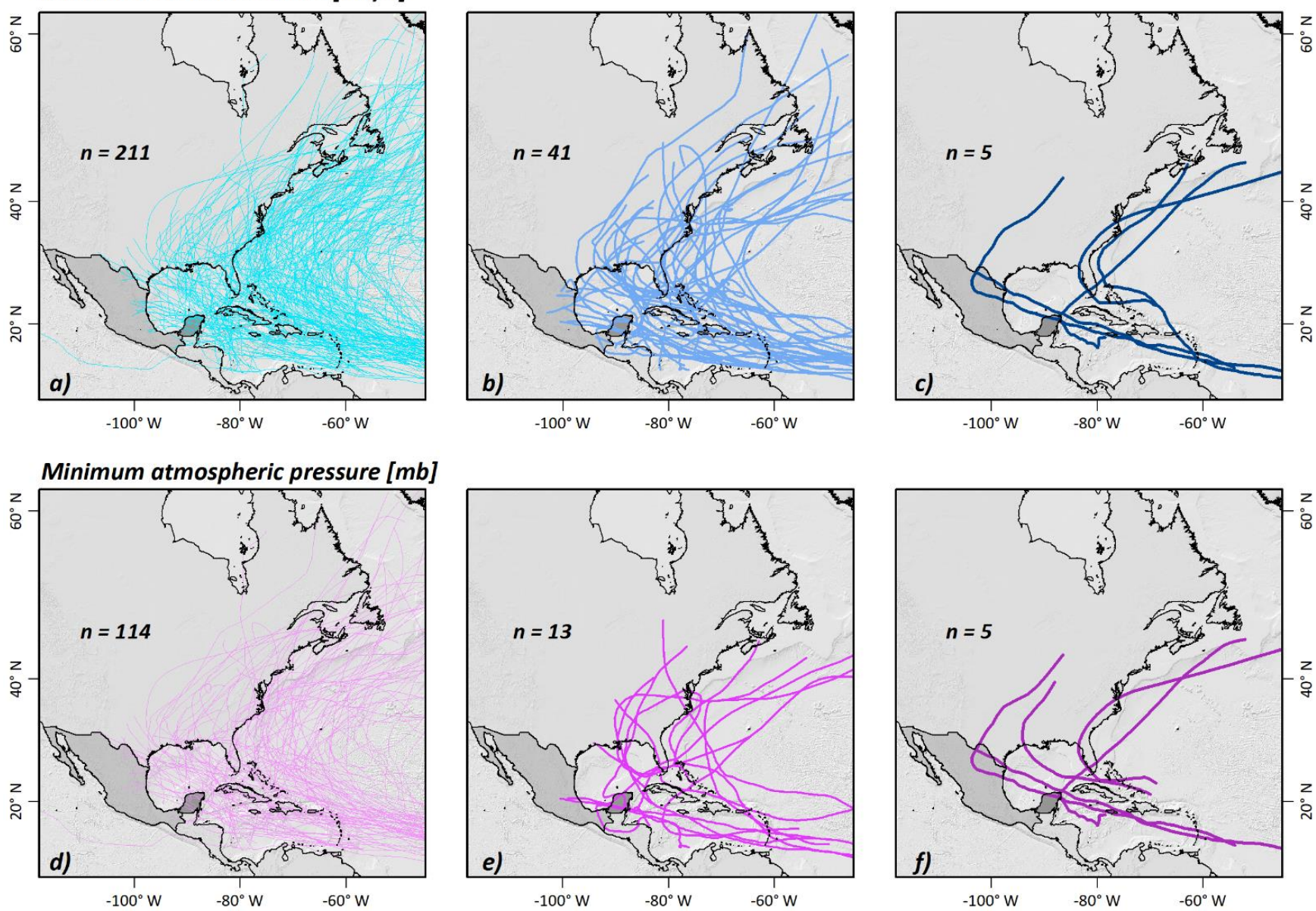

Symbology
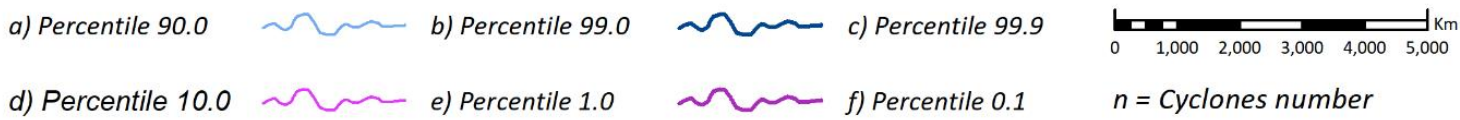

$n=$ Cyclones number

Figure 9. Cyclones that exceed the thresholds per variable: a) $\rangle=90.0$ and $\langle 99.0$; b) $\rangle=99.0$ and $\langle 99.9$; ) $\rangle=99.9$; d) $\langle=10.0$ and $>1.0 ;$ e) $<=1.0$ and $>0.1$; and f) $<=0.1$

4.2.2 Multivariate analysis between "maximum speed of sustained winds" and "minimum atmospheric pressure."

When comparing the thresholds' results for the selected variables, the resulting number of combinations was 10 , with a total of 260 cyclones that exceed the reference indices. The summary by combination and categories (SS) minimum and maximum achieved is shown in Figure 10.

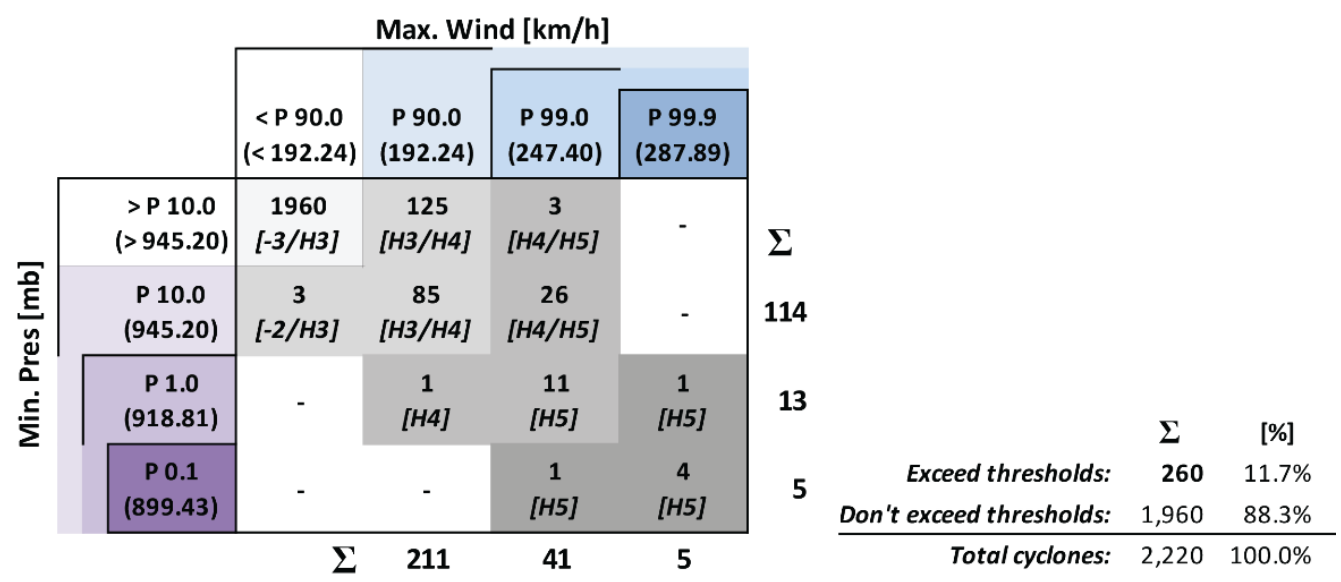

Figure 10. Extreme cyclones by combination of reference thresholds where: $\mathrm{P}=$ Percentile; ()$=$ Reference units; y [] = Min. and Max. Saffir-Simpson category 


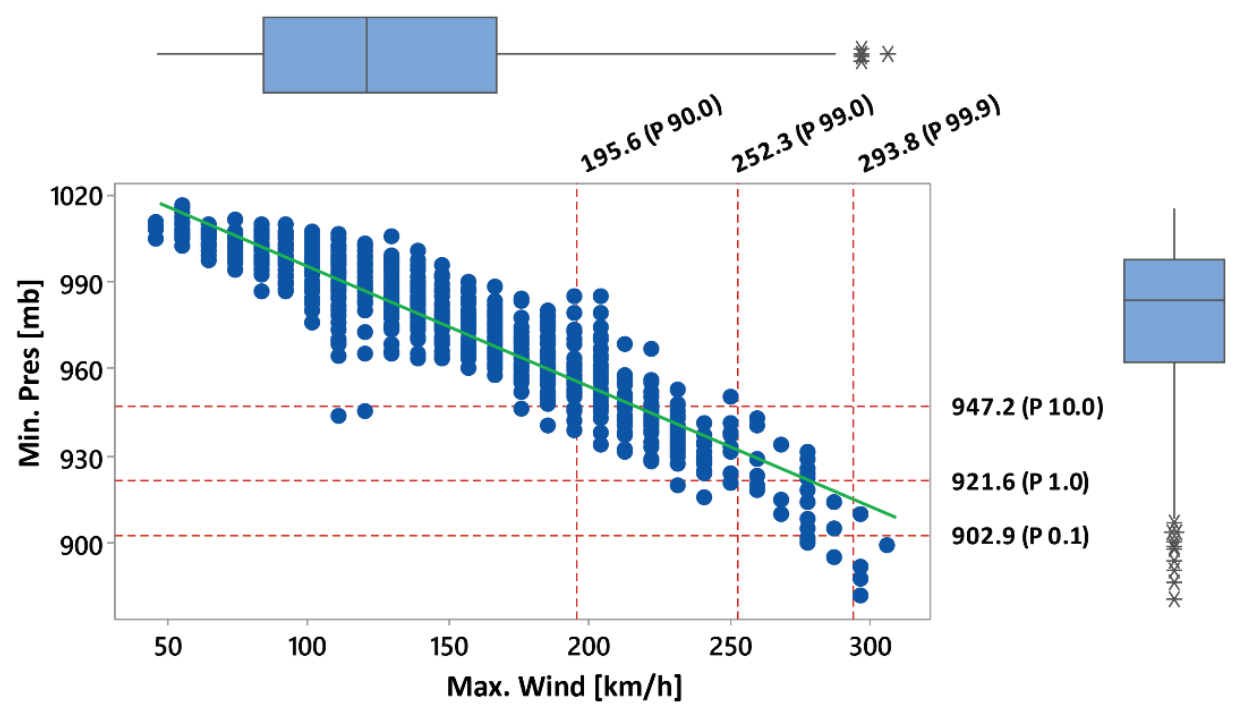

Figure 11. Comparison of linear regression and box plots for variables "maximum sustained wind speed" vs. "low atmospheric pressure."

where: Linear regression equation is: "Min. Pres = $1036-0.4125$ Max. Winds ", with an $\mathrm{R}^{2}$ of the order of -0895 , corroborate the relationship between the two variables inversely proportional

The values considered outliers decrease in quantity as the thresholds tend towards the extremes $(85,11$, and 4 cyclones, respectively). Observing Figure 11, the presence of 4 hurricanes: Not named (1935; H5), Allen (1980, H5); Gilbert (1988, H5); and Wilma (2005, H5)) categorized as "extremely rare" when exceeding the extraordinary reference indices of 0.1 and 99.9, with temporal equidistance between them of 45 , 8 and 17 years respectively, which does not show a defined pattern regarding the occurrence of events of such characteristics.

\subsubsection{Extreme cyclones in the North Atlantic Basin}

Discarding the reference thresholds suggested by the IPCC $[11,12], 47$ cyclones that meet the category of extreme events, where hurricane Jose (2017, H4) was the only one that did not reach continental or insular lands (Table 2).

The paths by combinations of thresholds (percentiles) are shown in Figure 12.

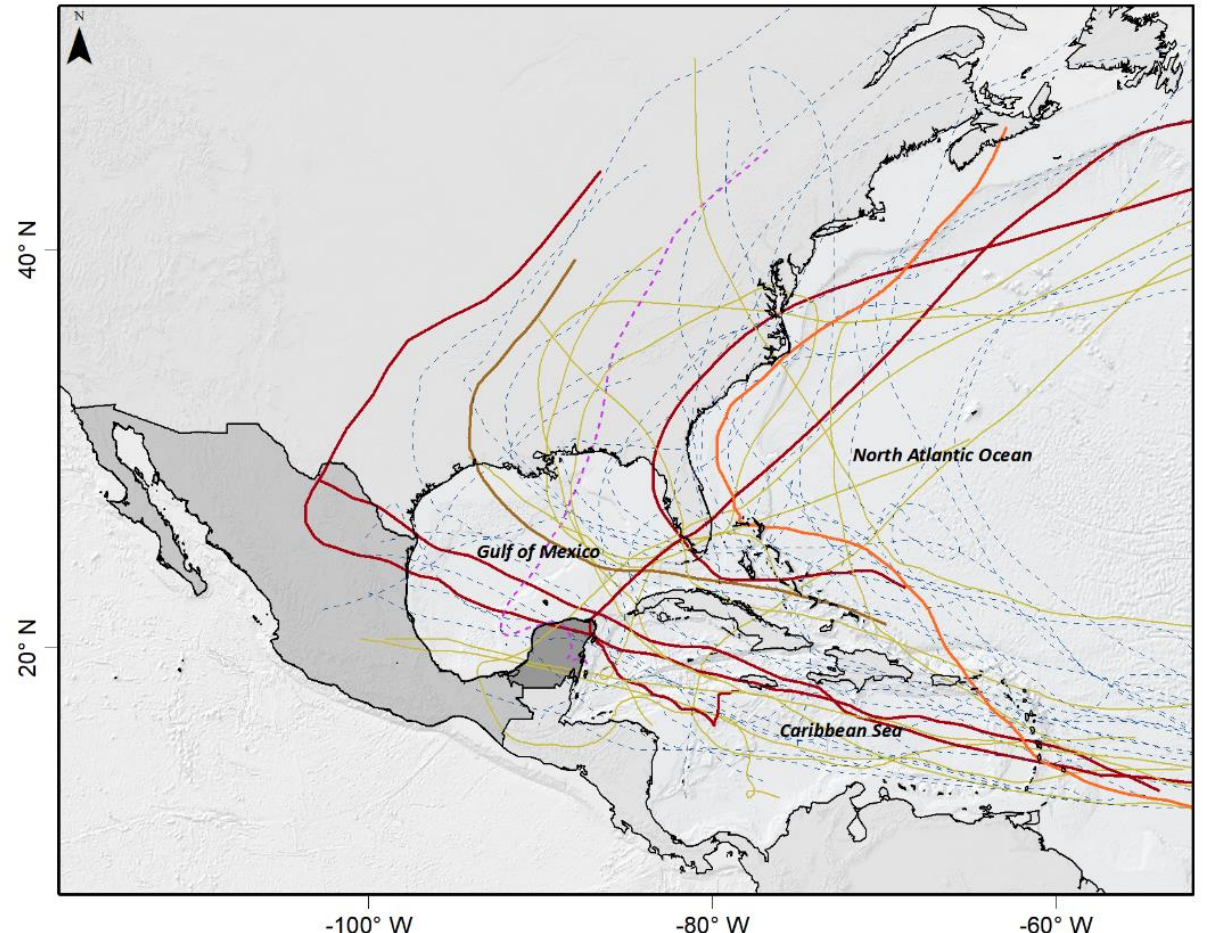

$-100^{\circ} \mathrm{W}$

$-80^{\circ} \mathrm{W}$

$-60^{\circ} \mathrm{W}$

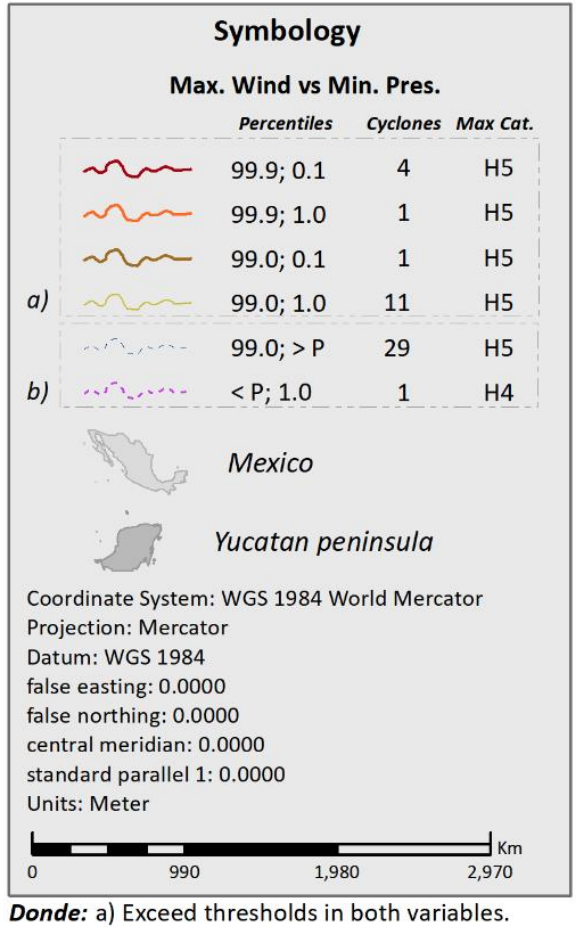

b) Exceed thresholds in a single variable.

Figure 12. Cyclones tracks in North Atlantic Basin between 1851-2019, categorized as extreme events for exceeding the thresholds selected for both variables 
Table 2. Cyclones by the combination of percentiles [\%] by variable. where: MxLf = Mexico landfall; YPLf = Yucatan Peninsula landfall; and NLf = No landfall

\begin{tabular}{|c|c|c|c|c|c|c|c|}
\hline Season & Name & S.S. Scale & Max. Wind $[\mathrm{km} / \mathrm{h}]$ & Pwind [\%] & Min. Pres [mb] & Ppres [\%] & Impact zone \\
\hline 1935 & Not named & 5 & 296.32 & 99.9 & 892 & 0.1 & \\
\hline 1980 & Allen & 5 & 305.58 & 99.9 & 899 & 0.1 & MxLf \\
\hline 1988 & Gilbert & 5 & 296.32 & 99.9 & 888 & 0.1 & YPLf \\
\hline 2005 & Wilma & 5 & 296.32 & 99.9 & 882 & 0.1 & YPLf \\
\hline 2019 & Dorian & 5 & 296.32 & 99.9 & 910 & 1.0 & \\
\hline 2005 & Rita & 5 & 287.06 & 99.0 & 895 & 0.1 & \\
\hline 1924 & Not named & 5 & 268.54 & 99.0 & 910 & 1.0 & \\
\hline 1932 & Not named & 5 & 277.8 & 99.0 & 918 & 1.0 & \\
\hline 1955 & Janet & 5 & 277.8 & 99.0 & 914 & 1.0 & YPLf \\
\hline 1969 & Camille & 5 & 277.8 & 99.0 & 900 & 1.0 & \\
\hline 1998 & Mitch & 5 & 287.06 & 99.0 & 905 & 1.0 & YPLf \\
\hline 2003 & Isabel & 5 & 268.54 & 99.0 & 915 & 1.0 & \\
\hline 2004 & Ivan & 5 & 268.54 & 99.0 & 910 & 1.0 & \\
\hline 2005 & Katrina & 5 & 277.8 & 99.0 & 902 & 1.0 & \\
\hline 2007 & Dean & 5 & 277.8 & 99.0 & 905 & 1.0 & YPLf \\
\hline 2017 & Irma & 5 & 287.06 & 99.0 & 914 & 1.0 & \\
\hline 2017 & Maria & 5 & 277.8 & 99.0 & 908 & 1.0 & \\
\hline 1928 & Not named & 5 & 259.28 & 99.0 & 929 & $>\mathbf{P}$ & \\
\hline 1929 & Not named & 4 & 250.02 & 99.0 & 924 & $>\mathbf{P}$ & \\
\hline 1930 & Not named & 4 & 250.02 & 99.0 & 933 & $>\mathbf{P}$ & \\
\hline 1933 & Not named & 5 & 259.28 & 99.0 & 940 & $>\mathbf{P}$ & MxLf \\
\hline 1933 & Not named & 5 & 259.28 & 99.0 & 929 & $>\mathbf{P}$ & YPLf \\
\hline 1938 & Not named & 5 & 259.28 & 99.0 & 940 & $>\mathbf{P}$ & \\
\hline 1953 & Carol & 5 & 259.28 & 99.0 & 929 & $>\mathbf{P}$ & \\
\hline 1961 & Carla & 5 & 277.8 & 99.0 & 931 & $>\mathbf{P}$ & \\
\hline 1961 & Hattie & 5 & 259.28 & 99.0 & 920 & $>\mathbf{P}$ & \\
\hline 1965 & Betsy & 4 & 250.02 & 99.0 & 941 & $>\mathbf{P}$ & \\
\hline 1967 & Beulah & 5 & 259.28 & 99.0 & 923 & $>P$ & YPLf \\
\hline 1971 & Edith & 5 & 259.28 & 99.0 & 943 & $>P$ & YPLf \\
\hline 1977 & Anita & 5 & 277.8 & 99.0 & 926 & $>P$ & MxLf \\
\hline 1979 & David & 5 & 277.8 & 99.0 & 924 & $>\mathbf{P}$ & \\
\hline 1992 & Andrew & 5 & 277.8 & 99.0 & 922 & $>P$ & \\
\hline 1998 & Georges & 4 & 250.02 & 99.0 & 937 & $>P$ & \\
\hline 1999 & Floyd & 4 & 250.02 & 99.0 & 921 & $>\mathbf{P}$ & \\
\hline 1999 & Lenny & 4 & 250.02 & 99.0 & 933 & $>\mathbf{P}$ & \\
\hline 2005 & Emily & 5 & 259.28 & 99.0 & 929 & $>\mathbf{P}$ & YPLf \\
\hline 2007 & Felix & 5 & 277.8 & 99.0 & 929 & $>\mathbf{P}$ & MxLf \\
\hline 2008 & Gustav & 4 & 250.02 & 99.0 & 941 & $>\mathbf{P}$ & \\
\hline 2010 & Igor & 4 & 250.02 & 99.0 & 924 & $>P$ & \\
\hline 2015 & Joaquin & 4 & 250.02 & 99.0 & 931 & $>P$ & \\
\hline 2016 & Matthew & 5 & 268.54 & 99.0 & 934 & $>P$ & \\
\hline 2017 & Jose & 4 & 250.02 & 99.0 & 938 & $>\mathbf{P}$ & NLf \\
\hline 2018 & Michael & 5 & 259.28 & 99.0 & 919 & $>\mathbf{P}$ & \\
\hline 1932 & Not named & 5 & 259.28 & 99.0 & & $>\mathbf{P}$ & \\
\hline 1964 & Cleo & 4 & 250.02 & 99.0 & 950 & $>\mathbf{P}$ & \\
\hline 1989 & Hugo & 5 & 259.28 & 99.0 & 918 & $>\mathbf{P}$ & \\
\hline 1995 & Opal & 4 & 240.76 & $<\mathbf{P}$ & 916 & 1.0 & YPLf \\
\hline
\end{tabular}

4.2.4 Cyclones categorized as extremes in the Yucatan Peninsula

According to the IPCC [11, 12] criteria, 30 extreme cyclones have impacted the Yucatan Peninsula (Table 3), 9 of which reached category H5. hurricanes Gilbert (1988) and Wilma (2005) are listed as "extremely rare," and hurricanes Janet (1955), Mitch (1998), and Dean (2007) in the "very rare" category by exceeding the 1.0 and 99.0 percentiles as well as Emily (2005) and Dean (2007) who exceeded the 99.0 percentile for wind speed. By discarding the IPCC thresholds, the number of cyclones categorized as extreme events is reduced to 10 .

$80 \%(\mathrm{n}=24)$ of the hurricanes impacting as extreme event category crossed the Peninsula transversely and uniformly in a southeast-northwest direction. 10\% $(\mathrm{n}=3)$ arrived from the north in a southwest direction: Not named (1888, H3); Isidore (2002, H3); and Mitch (1988, H5).

Cyclones as: Not named (1906, H3), Opal (1995, H4), Wilma (2005, H5), and Isidore (2002, H3) presented erratic trajectories, particularly Isidore, which enter the Peninsula along the north coast of the state of Yucatan with a southern direction, where little before reaching the state of Campeche, he made a $360^{\circ}$ loop to move to the northwest until he left the Gulf of Mexico.

Extreme events are mainly concentrated in the north and south, while the Peninsula center reported the minor cyclonic activity (Figure 13). 
Table 3. Cyclones by the combination of percentiles [\%] by variable that landfall the YP

\begin{tabular}{ccccccc}
\hline Season & Name & S.S. Scale & Max. Wind [km/h] & Pwind [\%] & Min. Pres [mb] & Ppres [\%] \\
\hline 1988 & Gilbert & 5 & 296.32 & $\mathbf{9 9 . 9}$ & 888 & $\mathbf{0 . 1}$ \\
2005 & Wilma & 5 & 296.32 & $\mathbf{9 9 . 9}$ & 882 & $\mathbf{0 . 1}$ \\
1955 & Janet & 5 & 277.8 & $\mathbf{9 9 . 0}$ & 914 & $\mathbf{1 . 0}$ \\
1998 & Mitch & 5 & 287.06 & $\mathbf{9 9 . 0}$ & 905 & $\mathbf{1 . 0}$ \\
2007 & Dean & 5 & 277.8 & $\mathbf{9 9 . 0}$ & 905 & $\mathbf{1 . 0}$ \\
1933 & Not named & 5 & 259.28 & $\mathbf{9 9 . 0}$ & 929 & $\mathbf{1 0 . 0}$ \\
1967 & Beulah & 5 & 259.28 & $\mathbf{9 9 . 0}$ & 923 & $\mathbf{1 0 . 0}$ \\
1971 & Edith & 5 & 259.28 & $\mathbf{9 9 . 0}$ & 943 & $\mathbf{1 0 . 0}$ \\
2005 & Emily & 5 & 259.28 & $\mathbf{9 9 . 0}$ & 929 & $\mathbf{1 0 . 0}$ \\
1995 & Opal & 4 & 240.76 & $\mathbf{9 0 . 0}$ & 916 & $\mathbf{1 . 0}$ \\
1880 & Not named & 4 & 240.76 & $\mathbf{9 0 . 0}$ & 931 & $\mathbf{1 0 . 0}$ \\
1974 & Carmen & 4 & 240.76 & $\mathbf{9 0 . 0}$ & 928 & $\mathbf{1 0 . 0}$ \\
2000 & Keith & 4 & 222.24 & $\mathbf{9 0 . 0}$ & 939 & $\mathbf{1 0 . 0}$ \\
2002 & Isidore & 3 & 203.72 & $\mathbf{9 0 . 0}$ & 934 & $\mathbf{1 0 . 0}$ \\
2017 & Harvey & 4 & 212.98 & $\mathbf{9 0 . 0}$ & 937 & $\mathbf{1 0 . 0}$ \\
1855 & Not named & 3 & 203.72 & $\mathbf{9 0 . 0}$ & & $>\mathbf{P}$ \\
1888 & Not named & 3 & 203.72 & $\mathbf{9 0 . 0}$ & & $>\mathbf{P}$ \\
1893 & Not named & 4 & 212.98 & $\mathbf{9 0 . 0}$ & 948 & $>\mathbf{P}$ \\
1903 & Not named & 3 & 194.46 & $\mathbf{9 0 . 0}$ & 958 & $>\mathbf{P}$ \\
1906 & Not named & 3 & 194.46 & $\mathbf{9 0 . 0}$ & 953 & $>\mathbf{P}$ \\
1909 & Not named & 3 & 194.46 & $\mathbf{9 0 . 0}$ & & $>$ P \\
1931 & Not named & 4 & 212.98 & $\mathbf{9 0 . 0}$ & & $>\mathbf{P}$ \\
1938 & Not named & 3 & 194.46 & $\mathbf{9 0 . 0}$ & 979 & $>\mathbf{P}$ \\
1944 & Not named & 3 & 194.46 & $\mathbf{9 0 . 0}$ & 973 & $>\mathbf{P}$ \\
1951 & Charlie & 4 & 212.98 & $\mathbf{9 0 . 0}$ & 968 & $>\mathbf{P}$ \\
1955 & Hilda & 3 & 194.46 & $\mathbf{9 0 . 0}$ & 952 & $>\mathbf{P}$ \\
1970 & Ella & 3 & 203.72 & $\mathbf{9 0 . 0}$ & 967 & $>\mathbf{P}$ \\
1975 & Eloise & 3 & 203.72 & $\mathbf{9 0 . 0}$ & 955 & $>\mathbf{P}$ \\
2010 & Karl & 3 & 203.72 & $\mathbf{9 0 . 0}$ & 956 & $>\mathbf{P}$ \\
1988 & Keith & 0 & 120.38 & $\mathbf{< P}$ & 945 & $\mathbf{1 0 . 0}$ \\
\hline & & & & & \\
\hline
\end{tabular}

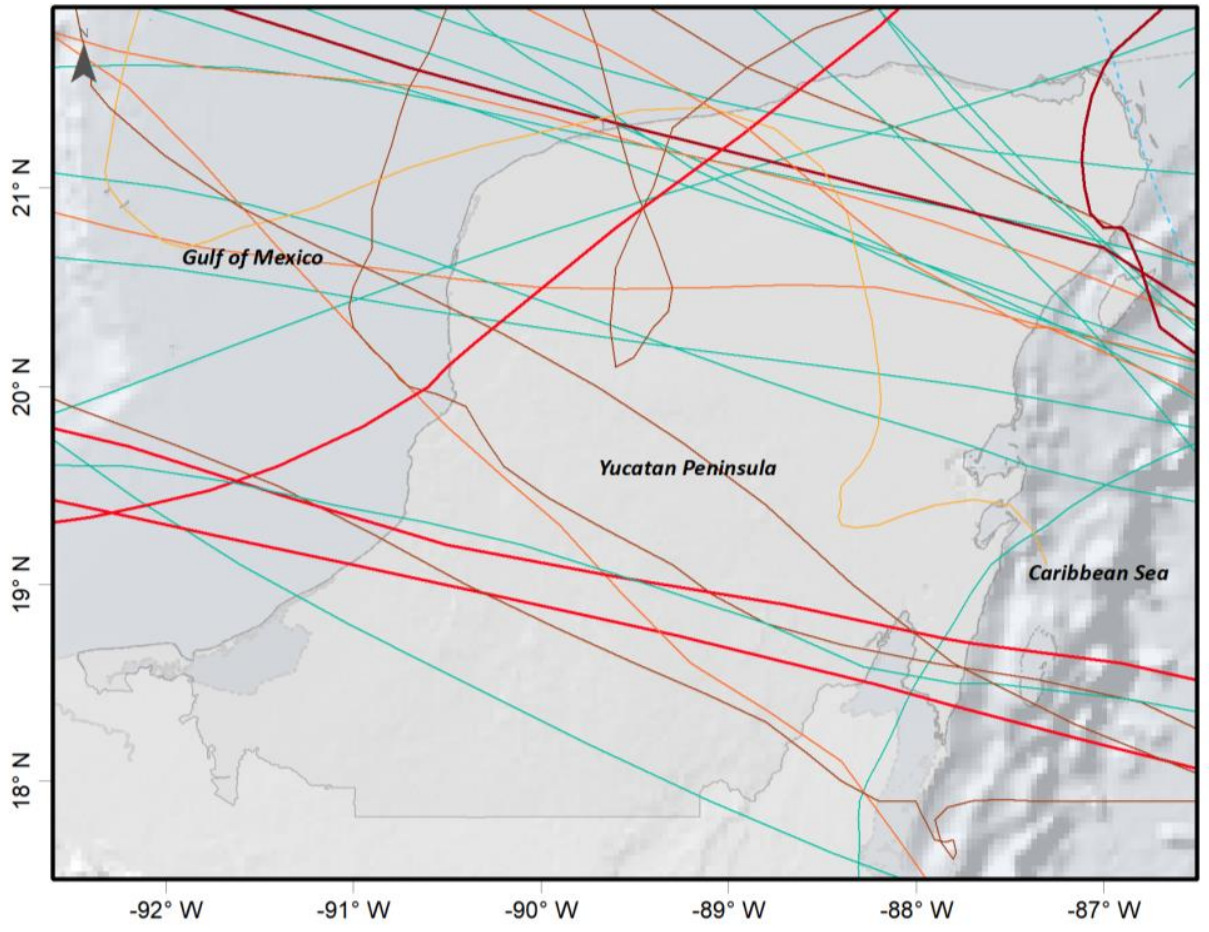

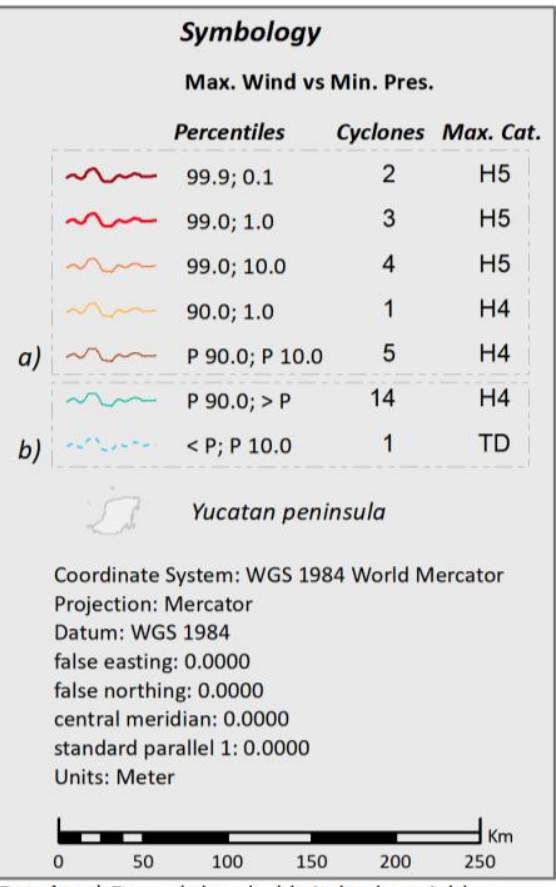

Donde: a) Exceed thresholds in both variables.

b) Exceed thresholds in a single variable.

Figure 13. Cyclones touched the Yucatan Peninsula between 1851-2019, categorized as extreme events for exceeding the thresholds selected for: a) both variables, and b) in a single variable

\section{DISCUSSION}

The analysis results do not show a significant increase in the number of cyclones because there are highlights a significant variability between seasons, which coincides with Walsh [43], who mentions that there has been little consensus regarding the increase in meteors. However, authors like Walsh et al. [44] agree that due to global warming, climate change scenarios 
foresee an increase in cyclonic activity, which will be evident towards the 1950 s of the present centuries.

In the case of intensity (magnitude), results show rates increase of change of approximately $37 \%$ in terms of the "maximum speed of sustained winds" and $19 \%$ for the "minimum atmospheric pressure. Although the results cannot be considered definitive or conclusive due to variability of the data's uncertainty, particularly before 1965 , our estimates are consistent with the forecasts of the current scenarios [12, 4447]. An example is an increase in cyclone intensity in hurricane categories $\mathrm{H} 4$ and $\mathrm{H} 5$ reported by Elsner et al. [48], Emanuel [49], and Webster [37], who studied periods ranging from 25, 30, and 35 years, respectively. Notwithstanding the differences in the time series' size, our findings are consistent with such studies' results.

In contrast, Klotzbach [24] and Kossin et al. [50] found no evidence of a trend of increasing magnitude of meteors, which can be attributed to the limited periods analyzed (20 years). According to Décamps [14] the detection of changes or trends will be a function of the temporality of the analyzed data and, as suggested by the WMO [9] periods of at least 30 years are required to study the behavior of the atmosphere.

Nevertheless, according to the general circulation models (GCMs) conducted by Appendini et al. [7], there is a clear trend tendency for higher intensity events to become more frequent due to a warming climate.

According to the definition of the IPCC [11, 12], 260 cyclones can be characterized as extreme events. However, when individually analyzing each one's characteristics, it was found that $39.62 \%$ barely reached the category at some point in their trajectory. Maximum H3, even more, within this range, are included the subtropical cyclone Charlie (1972) that did not reach the SS scale and tropical storm Keith (1988), which agrees with Camuffo et al. [13] who suggest that extreme events must be at least in the order of the 1st and 99th percentiles or higher

When analyzing the events that exceed the reference thresholds 1.0 and 99.0 (percentiles), all reached top categories of hurricane $\mathrm{H} 4$ and $\mathrm{H} 5$, causing the most significant damages and economic losses in the region according to the studies published by Alarcón [51]; Bonilla-Moheno [52]; CENAPRED [53]; and Frausto et al. [54], among others.

Most studies related to the intensity and occurrence of TCs consider as a parameter only the SS scale, which, being conceived as a categorical scale, does not allow direct comparisons between the values of the variables wind speed and atmospheric pressure, with the damages and affectations in the social and environmental systems.

The main difference between the studies found in the literature with the present one is that the analysis and classification of extreme events are carried out in terms of intensity on the SS scale and the effects caused by these phenomena, such is the case of the works published by Palacio-Aponte [55] where he evaluates the effects of the impact of hurricanes taking as a geo-indicator the posthurricane coastal morphology and the study of Emanuel [49] who determines a potential destructiveness index of hurricanes to through correlation with sea surface temperature.

Other cases are the studies carried out by Rey et al. [56] and Ruiz-Salcines et al. [57], where the effects of TCs were modeled as a direct function of the variables representing each phenomenon.

It is important to note that the evaluation and characterization of the damages caused by cyclonic events must consider both the increase in the population in the areas susceptible to being impacted, as well as the quality and type of infrastructure (vulnerability) so that the comparison between the Affectations in different spatio-temporal stages can be subjective.

\section{CONCLUSIONS}

The methodology used allowed identifying and categorizing extreme cyclones based on small-scale analysis (North Atlantic Basin) and long-time series. However, in the case of studies at larger scales focused on identifying and estimating the effects and damages from a socio-ecological context, we consider that reclassification should be carried out based on the maximum and minimum values of the variables "wind speed," "pressure atmospheric" and "precipitation" during its proximity and passage through the land.

It is recommended to study and analyze the reports generated by various instances on the characteristics and effects of each cyclone, such as, among others: a) the IBTrACS [58] online search engine that provides detailed information on each meteor; b) the "summaries of tropical cyclones" issued by CONAGUA [59]; c) case studies on the effects of cyclones related to the number of deaths, economic damages, damage to infrastructure and ecosystems, such as the works published by CENAPRED [60]; Rodríguez-Esteves et al. [61] and Tun et al. [62]; among others.

Given the probabilities of the occurrence of multiple extreme events simultaneously, as was Hurricane Cristobal in southern PY in June 2020, during the pandemic caused by COVID-19 [63]. The emergency preparedness and response processes will become increasingly complicated, resulting in increased risk to the population and the environment [7]. Identifying and characterizing extreme events will provide valuable information for the preparation of studies that provide elements to decision-makers within the framework of strengthening public policies.

The characterization of extreme events is useful to strengthen the knowledge of the resilience and vulnerability of infrastructure, means of production, and the environment.

The findings obtained in this study can provide helpful information for the delimitation of priority areas for the assessment of the vulnerability of urban areas and protected natural areas, since of the four hurricanes considered as "extremely rare," two of them $(50 \%)$ impacted the Yucatan Peninsula: Gilbert (1988, H5) and Wilma (2005, H5).

Given the results, we consider that the methodology applied in this study could be adapted to catalog different disturbing events such as the case of forest fires, drought, floods, among others. It could be useful to release comparisons and analysis between events based on their probabilities of occurrence, intensity, spatio-temporal dimensions and estimate socioecological systems' resilience capacities in specific areas.

\section{ACKNOWLEDGMENT}

The author thanked the University of Quintana Roo, the Laboratory of Space Observation, the Sustainable Development Division, and the National Council for Science and Technology (CONACYT, due to its Spanish acronym) for the scholarship granted (597620) to carry out doctoral studies in Sustainable Development in the Cozumel Academic Unit.

M. Geóg. Gabriel Sánchez Rivera. 


\section{REFERENCES}

[1] NHC. (2019). Glossary of NHC terms. Centro Nacional de Huracanes de los Estados Unidos de América. https://www.nhc.noaa.gov/aboutgloss.shtml.

[2] NHC. (2019). Tropical cyclone climatology. Centro Nacional de Huracanes de los Estados Unidos de América. https://www.nhc.noaa.gov/climo/.

[3] IBTrACS. (2019b). International best track archive for climate stewardship (IBTrACS). Technical Documentation. En National Oceanic and Atmospheric Administration, National Climatic Data Center. https://www.ncdc.noaa.gov/ibtracs/pdf/IBTrACS_versi on4_Technical_Details.pdf.

[4] Schott, T., Landsea, C., Hafele, G., Lorens, J., Thurm, H., Ward, B., Willis, M., Zaleski, W. (2012). The Saffir Simpson hurricane wind scale. National Hurricane Center, February, 1-4 http://www.nhc.noaa.gov/pdf/sshws.pdf.

[5] Vink, K., Ahsan, M.N. (2018). The benefits of cyclones: A valuation approach considering ecosystem services. Ecological Indicators, 95(1): 260-269. https://doi.org/10.1016/j.ecolind.2018.07.035

[6] UNEP. (2009). Environment for development: Ecosystem management programme: A new approach to sustainability $\quad$ capacity4dev. https://europa.eu/capacity4dev/unep/document/ecosyste m-management-programme-new-approachsustainability.

[7] Appendini, C.M., Meza-Padilla, R., Abud-Russell, S., Proust, S., Barrios, R.E., Secaira-Fajardo, F. (2019). Effect of climate change over landfalling hurricanes at the Yucatan Peninsula. Climatic Change, 157(3-4): 469482. https://doi.org/10.1007/s10584-019-02569-5

[8] Wisner, B., Blaikie, P., Cannon, T., Davis, I. (2003). At Risk: Natural Hazards, People's Vulnerability and Disasters (2nd ed.). Taylor \& Francis. https://www.preventionweb.net/publications/view/670.

[9] WMO. (2018). Guidelines on the definition and monitoring of extreme weather and climate events. Final Version. World Meteorological Organization.

[10] IBTrACS. (2019a). IBTrACS v04r00 - Online browsing. International Best Track Archive for Climate Stewardship (IBTrACS). NOAA https://www.ncdc.noaa.gov/ibtracs/index.php.

[11] IPCC. (2012). Managing the risks of extreme events and disasters to advance climate change adaptation. En C. B. Field, V. Barros, T. F. Stocker, \& Q. Dahe (Eds.), A Special Report of Working Groups I and II of the Intergovernmental Panel on Climate Change. Cambridge University

Press. https://doi.org/10.1017/CBO9781139177245

[12] IPCC. (2014). Future climate changes, risks and impacts. en climate change 2014: Synthesis report. Contribution of Working Groups I, II and III to the Fifth Assessment Report of the Intergovernmental Panel on Climate Change. https://doi.org/10.1017/CBO9781107415324

[13] Camuffo, D., della Valle, A., Becherini, F. (2020). A critical analysis of the definitions of climate and hydrological extreme events. Quaternary International, 538: 5-13. https://doi.org/10.1016/j.quaint.2018.10.008

[14] Décamps, H. (2008). Ecosystems and extreme climatic events. Comptes Rendus Geoscience, 340(9-10): $553-$ 563. https://doi.org/10.1016/j.crte.2008.08.004
[15] Martínez-Yrízar, A., Jaramillo, V.J., Maass, M., Búrquez, A., Parker, G., Álvarez-Yépiz, J.C., Araiza, S., Verduzco, A., Sarukhán, J. (2018). Resilience of tropical dry forest productivity to two hurricanes of different intensity in western Mexico. Forest Ecology and Management, 426: 53-60. https://doi.org/10.1016/j.foreco.2018.02.024

[16] Stephenson, D.B. (2008). Definition, diagnosis, and origin of extreme weather and climate events. En H. F. Diaz \& R. J. Murnane (Eds.), Diaz, H.F., Murnane, R.J. (Eds.), Climate Extremes and Society. Cambridge University Press, Cambridge. (pp. 11-23). Cambridge University https://doi.org/10.1017/CBO9780511535840.004

[17] WMO. (2015). Guidelines on the definition and monitoring of extreme weather and climate events. Draft version - First review by TT-DEWCE, no. December. World Meteorological Organization.

[18] Coles, S. (2001). An introduction to statistical modeling of extreme values. Springer, London. https://doi.org/10.1007/978-1-4471-3675-0

[19] Tiago de Oliveira, J. (1986). Extreme values and meteorology. Theoretical and Applied Climatology, 37(4): 184-193. https://doi.org/10.1007/BF00867576

[20] Lazos-Chavero, E., Mwampamba, T.H., García-Frapolli, E. (2018). Uncovering links between livelihoods, landuse practices, vulnerability and forests after hurricane Jova in Jalisco, Mexico. Forest Ecology and Management, 426: 27-38. https://doi.org/10.1016/j.foreco.2017.10.009

[21] Holland, G., Bruyère, C.L. (2014). Recent intense hurricane response to global climate change. Climate Dynamics, 42(3-4): https://doi.org/10.1007/s00382-013-1713-0

[22] Doval, J.P., Pérez, M.B., Acosta, J.O., Rodríguez, E. (2013). Caracterización de las trayectorias de los Ciclones Tropicales en la Cuenca Atlántica en relación con la actividad solar y otras variables. XI Congreso Cubano de Informática y Geociencias (GEOINFO’2013), 18.

[23] Vecchi, G.A., Knutson, T.R. (2008). On estimates of historical north atlantic tropical cyclone activity. Journal of Climate, 21(14): 3580-3600. https://doi.org/10.1175/2008JCLI2178.1

[24] Klotzbach, P.J. (2006). Trends in global tropical cyclone activity over the past twenty years (1986-2005). Geophysical Research Letters, 33(10). https://doi.org/10.1029/2006GL025881

[25] Palacio-Aponte, A.G. (1998). Susceptibilidad regional del terreno y riesgos por huracanes en la zona costera del Golfo de México. JAINA. EPOMEX, 9(2): 2.

[26] Ihl, T., Frausto-Martínez, O. (2014). El Cambio Climático y los huracanes en la Península de Yucatán. En Frausto Martínez, Oscar (Coord). Monitoreo de riesgo y desastre asociados a fenómenos hidrometeorológicos y cambio climático. (pp. 42-49). Universidad de Quintana Roo - REDESClim - CONACYT. https://www.mendeley.com/catalogue/monitoreoriesgo-y-desastre-asociados-fenómenoshidrometeorológicos-y-cambio-climático/.

[27] Frausto Martínez, O., Vazquez, A., Arroyo, L., Castillo, L., Hernández Aguilar, M.L. (2016). Hurricane resilience indicators in mexican caribbean coastal cities. International Journal of Safety and Security Engineering, 6(4): 755-763. https://doi.org/10.2495/SAFE-V6-N4- 
755-763

[28] Flanders Marine Institute. (2018). IHO Sea Areas, version 3. https://doi.org/10.14284/323

[29] United Nations. (2019). Population Division, World Population Prospects 2019, Online Edition. Rev. 1. Department of Economic and Social Affairs. https://population.un.org/wpp/Download/Standard/Popu lation/.

[30] Amante, C., Eakins, B.W. (2009). ETOPO1 1 ArcMinute Global Relief Model: Procedures, Data Sources and Analysis. NOAA Technical Memorandum NESDIS NGDC-24. National Geophysical Data Center, NOAA. https://doi.org/10.7289/V5C8276M

[31] Knapp, K.R., Diamond, H.J., Kossin, J.P., Kruk, M.C., Schreck III, C.J. (2018). International Best Track Archive for Climate Stewardship (IBTrACS) Project, Version 4. Subset: NA - North Atlantic. NOAA National Centers for Environmental Information. nongonvernment domain. https://data.nodc.noaa.gov/cgibin/iso?id=gov.noaa.ncdc:C01552.

[32] Saunders, M., Lea, A. (2019). Extended Range Forecast for Atlantic Hurricane Activity in 2020. Tropical Storm Risk (TSR), December $19 \quad$ 2019, 3. http://www.tropicalstormrisk.com/docs/TSRATLForeca stDec2020.pdf.

[33] Knapp, K.R., Kruk, M.C. (2010). Quantifying interagency differences in tropical cyclone best-track wind speed estimates. Monthly Weather Review, 138(4): 1459-1473. https://doi.org/10.1175/2009MWR3123.1

[34] Kruk, M.C., Knapp, K.R., Levinson, D.H. (2010). A technique for combining global tropical cyclone best track data. Journal of Atmospheric and Oceanic Technology, 27(4): 680-692. https://doi.org/10.1175/2009JTECHA1267.1

[35] Wessel, P., Smith, W.H.F. (1996). A global, selfconsistent, hierarchical, high-resolution shoreline database. Journal of Geophysical Research: Solid Earth, 101(B4): 8741-8743. https://doi.org/10.1029/96JB00104

[36] Wessel, P., Smith, W.H.F. (2017). GSHHG Version 2.3.7. A Global Self-consistent, Hierarchical, Highresolution Geography Database. https://www.soest.hawaii.edu/pwessel/gshhg/.

[37] Webster, P.J. (2005). Changes in tropical cyclone number, duration, and intensity in a warming environment. Science, 309(5742): 1844-1846. https://doi.org/10.1126/science.1116448

[38] Landsea, C.W., Vecchi, G.A., Bengtsson, L., Knutson, T.R. (2010). Impact of duration thresholds on Atlantic tropical cyclone counts. Journal of Climate, 23(10): 2508-2519. https://doi.org/10.1175/2009JCLI3034.1

[39] Sanders, C. (2016). A regression analysis of past hurricane patterns and a projection for the 2016 hurricane season. Florida Atlantic University.

[40] Harper, B.A. (2013). Best practice in tropical cyclone wind hazard modelling: In search of data and emptying the skeleton cupboard. 16th Australasian Wind Engineering Society Workshop, 10.

[41] Farfán, L.M. (2004). Regional observations during the landfall of tropical cyclone Juliette (2001) in Baja California, Mexico. Monthly Weather Review, 132(7): 1575-1589.

https://doi.org/10.1175/1520 0493(2004)132<1575:RODTLO>2.0.CO;2.

[42] Rey, W., Mendoza, E.T., Salles, P., Zhang, K., Teng, Y.C., Trejo-Rangel, M.A., Franklin, G.L. (2019).
Hurricane flood risk assessment for the Yucatan and Campeche State coastal area. Natural Hazards, 96(3): 1041-1065. https://doi.org/10.1007/s11069-019-03587-3

[43] Walsh, K.J.E. (2004). Tropical cyclones and climate change: Unresolved issues. Climate Research, 27(1): 7783. https://doi.org/10.3354/cr027077

[44] Walsh, K.J.E., McBride, J.L., Klotzbach, P.J., Balachandran, S., Camargo, S.J., Holland, G., Knutson, T.R., Kossin, J.P., Lee, T., Sobel, A., Sugi, M. (2016). Tropical cyclones and climate change. Wiley Interdisciplinary Reviews: Climate Change, 7(1): 65-89. https://doi.org/10.1002/wcc.371

[45] Solow, A.R. (2017). On detecting ecological impacts of extreme climate events and why it matters. Philosophical Transactions of the Royal Society B: Biological Sciences, 372(1723): 8-11. https://doi.org/10.1098/rstb.2016.0136

[46] Goodess, C.M. (2013). How is the frequency, location and severity of extreme events likely to change up to 2060? Environmental Science \& Policy, 27: S4-S14. https://doi.org/10.1016/j.envsci.2012.04.001

[47] Tapia-Palacios, M.A., García-Suárez, O., SotomayorBonilla, J., Silva-Magaña, M.A., Pérez-Ortíz, G., Espinosa-García, A.C., Ortega-Huerta, M.A., DíazÁvalos, C., Suzán, G., Mazari-Hiriart, M. (2018). Abiotic and biotic changes at the basin scale in a tropical dry forest landscape after Hurricanes Jova and Patricia in Jalisco, Mexico. Forest Ecology and Management, 426: 18-26. https://doi.org/10.1016/j.foreco.2017.10.015

[48] Elsner, J.B., Kossin, J.P., Jagger, T.H. (2008). The increasing intensity of the strongest tropical cyclones. Nature, 455(7209): https://doi.org/10.1038/nature07234

[49] Emanuel, K. (2005). Increasing destructiveness of tropical cyclones over the past 30 years. Nature, 436(7051): 686-688. https://doi.org/10.1038/nature03906

[50] Kossin, J.P., Knapp, K.R., Vimont, D.J., Murnane, R.J., Harper, B.A. (2007). A globally consistent reanalysis of hurricane variability and trends. Geophysical Research Letters, $34(4)$ : https://doi.org/10.1029/2006GL028836

[51] Rodríguez-Alarcón, M. N. (2019). El huracán Janet y el desastre de 1955 en Quintana Roo: estudio de una coyuntura crítica. Antrópica. Revista de Ciencias Sociales y Humanidades, 161-190. https://antropica.com.mx/ojs2/index.php/AntropicaRCS H/article/view/196.

[52] Bonilla-Moheno, M. (2010). Damage and recovery of forest structure and composition after two subsequent hurricanes in the Yucatan Peninsula. Caribbean Journal of Science, 46(2-3): 240-248. https://doi.org/10.18475/cjos.v46i2.a12

[53] CENAPRED. (2005a). Características e Impacto Socioeconómico del huracán 'Emily' en Quintana Roo, Yucatán, Tamaulipas y Nuevo León en Julio de 2005.

[54] Frausto Martínez, O., Vázquez Sosa, A.B., Colin Olivares, O., Hernández Aguilar, M.L., Arroyo Arcos, L., David Velázquez Torres, D. (2018). Monitoreo de indicadores de resiliencia urbana ante huracanes para las ciudades costeras: Playa del Carmen, caribe mexicano. En Esteves Juan Manuel Rodríguez y Rodríguez, C. M. W., \& Aguilar, M. L. R. Riesgo de desastres en México: eventos hidrometeorológicos y climáticos, pp. 29-55. https://www.imta.gob.mx/biblioteca/libros_html/desastr 
es-mexico/Libro-Riesgo-desastres-en-Mexico.pdf.

[55] Palacio-Aponte, G. (2010). Amenaza por huracanes. Interciencia, 35: 400-406. https://www.interciencia.net/wpcontent/uploads/2018/01/400-PALACIOS-7.pdf.

[56] Rey, W., Salles, P., Torres-Freyermuth, A., RuízSalcines, P., Teng, Y.C., Appendini, CM., QuinteroIbáñez, J. (2019). Spatiotemporal Storm Impact on the Northern Yucatan Coast during Hurricanes and Central American Cold Surge Events. Journal of Marine Science and Engineering, $\quad 8(1)$ : 2 https://doi.org/10.3390/jmse8010002

[57] Ruiz-Salcines, P., Appendini, C. M., Salles, P., Rey, W., Vigh, J.L. (2020). On the use of synthetic tropical cyclones and hypothetical events for storm surge assessment under climate change. Natural Hazards, 105(1): 431-459. https://doi.org/10.1007/s11069-02004318-9

[58] IBTrACS. (2020). Browse IBTrACS http://ibtracs.unca.edu/index.php?name=browse-yearbasin.

[59] CONAGUA. (2020). Consulta de historial y resumenes de ciclones tropicales. Información Historica. https://smn.conagua.gob.mx/es/ciclonestropicales/informacion-historica.

[60] CENAPRED. (2005). Características e impacto socioeconómico de los huracanes 'Stan' y 'Wilma' en la República Mexicana en 2005. p. 322, 2006.

[61] Rodríguez Esteves, J.M., Welsh Rodríguez, C.M., Romo Aguilar, M.L., Travieso Bello, A.C. (Coords). (2018). Riesgo de desastres en México: eventos hidrometeorológicos y climáticos. Instituto Mexicano de Tecnología del Agua. https://www.imta.gob.mx/biblioteca/libros_html/desastr es-mexico/Libro-Riesgo-desastres-en-Mexico.pdf.

[62] Tun, J., Perdigón, T., Chalé, G., Gil, C. (2015). Impacto Socioeconómico del Huracán Wilma en la Localidad de Playa del Carmen. Observatorio Urbano de la Riviera Maya. Observatorio Urbano Local de Playa del Carmen.

[63] Frausto-Martínez, O., Aguilar-Becerra, C.D., ColínOlivares, O., Sánchez-Rivera, G., Hafsi, A., ContrerasTax, A.F., Uhu-Yam, W.D. (2020). COVID-19, Storms, and Floods: Impacts of Tropical Storm Cristobal in the Western Sector of the Yucatan Peninsula, Mexico. Sustainability, $12(23)$ : https://doi.org/10.3390/su12239925

\section{NOMENCLATURE}

km/h Kilometer/hour

$\mathrm{mb} \quad$ Millibars 